\title{
Simulation of the interannual variations of aerosols in China: role of variations in meteorological parameters
}

\author{
Q. Mu ${ }^{1,2}$ and H. Liao ${ }^{1}$ \\ ${ }^{1}$ State Key Laboratory of Atmospheric Boundary Layer Physics and Atmospheric Chemistry, Institute of Atmospheric \\ Physics, Chinese Academy of Sciences, Beijing, China \\ ${ }^{2}$ Graduate University of Chinese Academy of Sciences, Beijing, China
}

Correspondence to: H. Liao (hongliao@mail.iap.ac.cn)

Received: 18 March 2014 - Published in Atmos. Chem. Phys. Discuss.: 7 May 2014

Revised: 31 July 2014 - Accepted: 10 August 2014 - Published: 16 September 2014

\begin{abstract}
We used the nested grid version of the global three-dimensional Goddard Earth Observing System chemical transport model (GEOS-Chem) to examine the interannual variations (IAVs) of aerosols over heavily polluted regions in China for years 2004-2012. The role of variations in meteorological parameters was quantified by a simulation with fixed anthropogenic emissions at year 2006 levels and changes in meteorological parameters over 20042012. Simulated $\mathrm{PM}_{2.5}$ (particles with a diameter of $2.5 \mu \mathrm{m}$ or less) aerosol concentrations exhibited large IAVs in North China (NC; $32-42^{\circ} \mathrm{N}, 110-120^{\circ} \mathrm{E}$ ), with regionally averaged absolute percent departure from the mean (APDM) values of $17,14,14$, and $11 \%$ in December-JanuaryFebruary (DJF), March-April-May (MAM), June-JulyAugust (JJA), and September-October-November (SON), respectively. Over South China (SC; $22-32^{\circ} \mathrm{N}, 110-120^{\circ} \mathrm{E}$ ), the IAVs in $\mathrm{PM}_{2.5}$ were found to be the largest in JJA, with the regional mean APDM values of $14 \%$ in JJA and of about $9 \%$ in other seasons. The concentrations of $\mathrm{PM}_{2.5}$ over the Sichuan Basin (SCB; $27-33^{\circ} \mathrm{N}, 102-110^{\circ} \mathrm{E}$ ) were simulated to have the smallest IAVs among the polluted regions examined in this work, with APDM values of 8-9 \% in all seasons. All aerosol species (sulfate, nitrate, ammonium, black carbon, and organic carbon) were simulated to have the largest IAVs over NC in DJF, corresponding to the large variations in meteorological parameters over NC in this season. Process analyses were performed to identify the key meteorological parameters that determined the IAVs of different aerosol species in different regions. While the variations in temperature and specific humidity, which influenced the gasphase formation of sulfate, jointly determined the IAVs of
\end{abstract}

sulfate over NC in both DJF and JJA, wind (or convergence of wind) in DJF and precipitation in JJA were the dominant meteorological factors to influence IAVs of sulfate over SC and the SCB. The IAVs in temperature and specific humidity influenced gas-to-aerosol partitioning, which were the major factors that led to the IAVs of nitrate aerosol in China. The IAVs in wind and precipitation were found to drive the IAVs of organic carbon aerosol. We also compared the IAVs of aerosols simulated with variations in meteorological parameters alone with those simulated with variations in anthropogenic emissions alone; the variations in meteorological fields were found to dominate the IAVs of aerosols in northern and southern China over 2004-2012. Considering that the IAVs in meteorological fields are mainly associated with natural variability in the climate system, the IAVs in aerosol concentrations driven by meteorological parameters have important implications for the effectiveness of shortterm air quality control strategies in China.

\section{Introduction}

Aerosols are major air pollutants that have adverse effects on human health, reduce atmospheric visibility, and influence global climate change. With the rapid economic development in China over the past decades, concentrations of aerosols are now among the highest in the world (Fu et al., 2008; Cao et al., 2012; Sun et al., 2013), driven mainly by the increases in direct and precursor emissions (Streets et al., 2003). Aerosol concentrations in China have variations on different timescales (Zhang et al., 2010a; Zhu et al., 
2012); we aim to understand interannual variations (IAVs) of aerosols in this study. Understanding interannual variations in aerosols driven by variations in meteorological parameters is especially important for air pollution control. For example, the Action Plan for Air Pollution Prevention and Control released by the State Council of China in 2013 aims to reduce the annual mean $\mathrm{PM}_{2.5}$ concentrations in the regions of Beijing-Tianjin-Hebei, Yangtze Delta, and Pearl River delta by 25,20 , and $15 \%$ respectively, as the concentrations in year 2017 are compared with those in 2012. The role of interannual variations in meteorological parameters needs to be separated from the impact of the reductions in emissions in these targeted reductions.

The IAVs of aerosols were usually quantified in previous studies by statistical variables such as standard deviation (SD), relative standard deviation (RSD), mean absolute deviation (MAD), and absolute percent departure from the mean (APDM), which are defined as

$\mathrm{SD}=\sqrt{\frac{1}{n} \sum_{i=1}^{n}\left(C_{i}-\frac{1}{n} \sum_{i=1}^{n} C_{i}\right)^{2}}$,

$\mathrm{RSD}=100 \% \times \mathrm{SD} /\left(\frac{1}{n} \sum_{i=1}^{n} C_{i}\right)$

$\mathrm{MAD}=\frac{1}{n} \sum_{i=1}^{n}\left|C_{i}-\frac{1}{n} \sum_{i=1}^{n} C_{i}\right|$

$\mathrm{APDM}=100 \% \times \mathrm{MAD} /\left(\frac{1}{n} \sum_{i=1}^{n} C_{i}\right)$

where $C_{i}$ is aerosol concentration of year $i$, and $n$ is the number of years examined. Therefore SD and MAD represent the absolute IAVs in aerosol concentration, and RSD and APDM represent the IAVs relative to the average concentration over the $n$ years.

Large IAVs of aerosols have been reported in previous studies for different aerosol species in different regions. Mahowald et al. (2003) showed that annual mean mineral dust concentrations measured at 10 sites in the United States over 1979-2000 had RSD values of 57-101\%. Habib et al. (2006) found by using the Total Ozone Mapping Spectrometer absorbing aerosol index data sets that the absorbing aerosol column burdens averaged over April-May of 1981-1992 exhibited a RSD of $16-30 \%$ in different regions of India. Alston et al. (2012) showed by using ground-based measurements at 41 sites in the southeastern United States (29 sites of $\mathrm{PM}_{2.5}$ measurements provided by Environmental Protection Agency and 12 sites by Georgia Dept. of Natural Resources) that monthly mean $\mathrm{PM}_{2.5}$ concentrations in that region had APDM values of 5-10\% over 2000-2009. They also showed by using three sets of aerosol optical depth (AOD) from Moderate Resolution Imaging Spectroradiometer (MODIS) Terra,
Multi-angle Imaging Spectroradiometer Terra, and MODIS Aqua that monthly mean AOD in the southeastern United States had RSD values of 15-25\% over 2000-2009.

Observations and modeling studies have also shown that aerosols in China have large IAVs. Qu et al. (2010) reconstructed $\mathrm{PM}_{10}$ aerosol concentrations at 86 Chinese cities using records of air pollution index from summer 2000 to winter 2006, and reported that seasonal-median $\mathrm{PM}_{10}$ levels exhibited APDM values of $15-35 \%$ in those cities. Yang et al. (2011) collected weekly samples of carbonaceous aerosols over 2005-2008 at two sites in Beijing and reported that year-to-year changes in emission and meteorology altered annual-average fine organic carbon (OC) concentrations at the rural site in Beijing by as much as $27 \%$ over the observational time period.

The IAVs of aerosols are influenced by both emissions and meteorology. Meteorological parameters influence aerosol concentrations through altering emissions, chemical reactions, transport, and deposition. For example, increases in temperature enhance chemical production of sulfate in the atmosphere (Aw and Kleeman, 2003; Dawson et al., 2007; Kleeman, 2008) and decrease nitrate aerosol formation (Bellouin et al., 2011; Liao et al., 2006; Pye et al., 2009; Racherla and Adams, 2006). Aerosol concentrations decrease with increasing precipitation as wet deposition provides the main aerosol sink (Balkanski et al., 1993; Dawson et al., 2007), and changes in ventilation (wind speed, mixing depth) have large impacts on aerosols since aerosols are mainly influenced by local meteorological conditions. Tai et al. (2010) found that daily variation in meteorology as described by the multiple linear regression could explain up to $50 \%$ of $\mathrm{PM}_{2.5}$ variability based on an 11-year (1998-2008) observational record over the contiguous United States, with temperature, relative humidity, precipitation, and circulation all being important predictors.

Since concentrations of chemical species are the net results from comprehensive physical and chemical processes, the integrated process rates (IPR) (Im et al., 2011) have been used to identify the dominant processes (such as horizontal and vertical transport, emissions of primary species, gas-phase chemistry, dry deposition, cloud processes, and aerosol processes) that influence the concentrations of chemical species in the Community Multi-scale Air Quality model (CMAQ) for episodic events (Jose et al., 2002; Goncalves et al., 2009) as well as for yearly (Zhang et al., 2009) to decadal simulations (Civerolo et al., 2010). The IPR analyses in these studies ranked the roles of different processes in the formation and fate of a chemical species. For example, the horizontal flows and gas-phase chemical reactions in the morning and the vertical flows in the afternoon were found to be the main factors in the formation of surface $\mathrm{O}_{3}$ during a photochemical pollution episode in the coastal area of southwestern Europe in summer (Goncalves et al., 2009). Recently, a similar process analysis scheme was implemented within the Weather Research and Forecasting model coupled with 
Chemistry (WRF Chem) to understand the key photochemical and physical processes for the formation of $\mathrm{O}_{3}$ (Jiang et al., 2012) and $\mathrm{PM}_{10}$ (Jiang et al., 2013).

The scientific goals of this work are (1) to quantify the IAVs in surface-layer aerosol concentrations in China resulted from the variations in meteorological conditions during the 2004-2012 period, using the global threedimensional chemical transport model GEOS-Chem (Goddard Earth Observing System chemical transport model), and (2) to identify the key meteorological parameters that influenced the IAVs of aerosols in different polluted regions of China by the IPR analyses. Section 2 describes the model, emissions, and numerical experiments. Section 3 presents simulated distributions of aerosols and IAVs in concentrations of different aerosol species in China averaged over 2004-2012. The key meteorological parameters that influenced IAVs of aerosols are examined by IPR in Sect. 4. Section 5 discusses the impacts of anthropogenic and natural emissions on IAVs of aerosols in China.

\section{Model description and numerical experiments}

\subsection{GEOS-Chem Model}

We simulated aerosols using the global chemical transport model GEOS-Chem (version 9-01-02) driven by the GEOS-5 assimilated meteorological fields from the Goddard Earth Observing System of the NASA Global Modeling and Assimilation Office. We used the nested-grid capability of the GEOS-Chem model over East Asia $\left(11^{\circ} \mathrm{S}-55^{\circ} \mathrm{N}\right.$, $\left.70-150^{\circ} \mathrm{E}\right)$ with a horizontal resolution of $0.5^{\circ}$ latitude by $0.667^{\circ}$ longitude and 47 vertical layers up to $0.01 \mathrm{hPa}$ (Chen et al., 2009). Chemical boundary conditions were from the global simulations performed at $4^{\circ} \times 5^{\circ}$ horizontal resolution.

The GEOS-Chem model has fully coupled $\mathrm{O}_{3}-\mathrm{NO}_{\mathrm{x}}-$ hydrocarbon chemistry and aerosols including sulfate $\left(\mathrm{SO}_{4}^{2-}\right)$, nitrate $\left(\mathrm{NO}_{3}^{-}\right)$, ammonium $\left(\mathrm{NH}_{4}^{+}\right)$(Park et al., 2004; Pye et al., 2009), OC and BC (black carbon; Park et al., 2003), sea salt (Alexander et al., 2005), and mineral dust (Fairlie et al., 2007). The gas-aerosol partitioning of nitric acid and ammonia is calculated using the ISORROPIA II thermodynamic equilibrium model (Fountoukis and Nenes, 2007). Wet deposition of soluble aerosols and gases follows the scheme of Liu et al. (2001) and dry deposition follows a standard resistance-in-series model of Wesely (1989). We do not examine IAVs of mineral dust and sea salt aerosols in this study, because sea salt aerosol is not a major aerosol component in China based on measurements (Ye et al., 2003; Duan et al., 2006) and mineral dust aerosol simulation has very large uncertainties (Fairlie et al., 2007, 2010).

Considering the large uncertainties in chemistry schemes of secondary organic aerosol (SOA), SOA in our simulations was assumed to be the $10 \%$ carbon yield of OC from bio- genic terpenes (Park et al., 2003) and $2 \%$ carbon yield of OC from biogenic isoprene (van Donkelaar et al., 2007).

\subsection{Emissions}

Global emissions of aerosol precursors and aerosols in the GEOS-Chem model generally follow Park et al. (2003) and Park et al. (2004). Anthropogenic emissions of $\mathrm{NO}_{\mathrm{x}}, \mathrm{SO}_{2}$, $\mathrm{BC}$, and OC (including emissions from power, industry, residential, and transportation sources) in the Asian domain are overwritten by David Streets' 2006 emission inventory (http: //mic.greenresource.cn/intex-b2006) (Zhang et al., 2009) in this work. Estimates of $\mathrm{NH}_{3}$ emissions in China showed large uncertainties in previous studies (Streets et al., 2003; Kim et al., 2006; Zhang et al., 2010b; Huang et al., 2011, 2012). We used in our simulations the most recent estimate of $\mathrm{NH}_{3}$ emissions in China by Huang et al. (2012), which was $9.8 \mathrm{Tg} \mathrm{yr}^{-1}$, instead of $13.5 \mathrm{Tg} \mathrm{yr}^{-1}$ from Streets et al. (2003). Monthly variations in $\mathrm{SO}_{2}, \mathrm{NO}_{\mathrm{x}}$, and $\mathrm{NH}_{3}$ follow those in Wang et al. (2013). Table 1 summarizes year 2006 annual emissions of $\mathrm{NO}_{\mathrm{x}}, \mathrm{SO}_{2}, \mathrm{NH}_{3}, \mathrm{OC}$, and $\mathrm{BC}$ in Asia $\left(70-150^{\circ} \mathrm{E}, 11^{\circ} \mathrm{S}-55^{\circ} \mathrm{N}\right)$ and eastern China (98$\left.130^{\circ} \mathrm{E}, 20-55^{\circ} \mathrm{N}\right)$.

Natural $\mathrm{NO}_{\mathrm{x}}$ emissions from lightning were described by Sauvage et al. (2007) and Murray et al. (2012), and those from soil were described by Yienger and Levy (1995). Natural $\mathrm{NH}_{3}$ emissions from soil, vegetation, and the oceans were from the Global Emissions Inventory Activity inventory (Bouwman et al., 1997). Biomass burning emissions were from the monthly Global Fire Emissions Database-v2 inventory (van der Werf et al., 2006). Biogenic VOC (volatile organic compounds) emissions were calculated from the Model of Emissions of Gases and Aerosols from Nature (Guenther et al., 2006).

\subsection{Numerical experiments}

To quantify IAVs of aerosols over 2004-2012, we performed the following simulations of aerosols in China using the GEOS-Chem model driven by the GEOS-5 meteorological fields:

1. ANNmet: the simulation to examine how the IAVs of aerosols were influenced by variations in meteorological parameters. Meteorological fields, natural emissions, and biomass burning emissions were allowed to vary from 2004 to 2012, while anthropogenic emissions were kept at the year 2006 values.

2. ANNmet_ATM: sensitivity simulation for 2004-2012 to examine the sensitivity of IAVs of aerosols to variations in atmospheric conditions alone. All natural emissions (such as soil $\mathrm{NO}_{\mathrm{x}}$, lightning $\mathrm{NO}_{\mathrm{x}}$ as well as biogenic sources) that were sensitive to meteorological parameters were turned off. Anthropogenic emissions were kept at the year 2006 values. Meteorological fields 


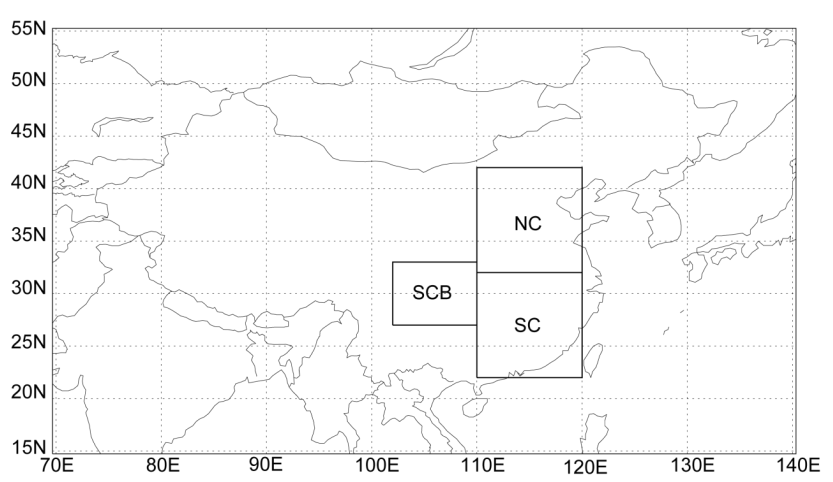

Figure 1. Polluted regions examined in this study, including North China $\left(\mathrm{NC}, 32-42^{\circ} \mathrm{N}, 110-120^{\circ} \mathrm{E}\right)$, South China $\left(\mathrm{SC}, 22-32^{\circ} \mathrm{N}\right.$, $\left.110-120^{\circ} \mathrm{E}\right)$, and the Sichuan Basin (SCB, $\left.27-33^{\circ} \mathrm{N}, 102-110^{\circ} \mathrm{E}\right)$.

and biomass burning emissions were allowed to vary from 2004 to 2012.

3. ANNemis: the simulation to examine how the IAVs of aerosols were influenced by variations in anthropogenic emissions. Anthropogenic and biomass burning emissions were allowed to vary from 2004 to 2012. Meteorological parameters and hence natural emissions were kept at the year 2006 values.

4. ANNall: simulation of aerosols for years 20042012 with yearly varying meteorological parameters, biomass, natural and anthropogenic emissions. The IAVs in anthropogenic emissions over 2004-2012 were obtained by using scaling factors; the annual scaling factors for $\mathrm{NO}_{\mathrm{x}}$ were taken from Zhang et al. (2012) and those for $\mathrm{SO}_{2}, \mathrm{OC}$, and $\mathrm{BC}$ were taken from $\mathrm{Lu}$ et al. (2011).

In ANNmet, the IAVs in meteorological fields influenced aerosol concentrations in two ways. First, changes in meteorological parameters influenced chemical reactions, transport, and deposition of aerosols. Second, precursor emissions from natural sources varied with meteorological fields. We performed one sensitivity simulation ANNmet_ATM with natural emissions turned off. The differences between ANNmet and ANNmet_ATM represent the differences in IAVs with and without natural emissions. Biomass burning emissions were partly anthropogenic and partly natural, which were allowed to vary over 2004-2012 in all the simulations. A comparison of ANNmet and ANNemis tells us the relative importance of variations in meteorological parameters and anthropogenic emissions in IAVs of aerosols.

The presentations of the IAVs of aerosols will be focused on three polluted regions in China, $\mathrm{NC}\left(32-42^{\circ} \mathrm{N}\right.$, $\left.110-120^{\circ} \mathrm{E}\right), \mathrm{SC}\left(22-32^{\circ} \mathrm{N}, 110-120^{\circ} \mathrm{E}\right)$, and the SCB $(27-$ $\left.33^{\circ} \mathrm{N}, 102-110^{\circ} \mathrm{E}\right)$, as defined in Fig. 1.
Table 1. Summary of annual emissions of aerosols and aerosol precursors in Asia $\left(70-150^{\circ} \mathrm{E}, 11^{\circ} \mathrm{S}-55^{\circ} \mathrm{N}\right)$ and eastern China (98$\left.130^{\circ} \mathrm{E}, 20-55^{\circ} \mathrm{N}\right)$.

\begin{tabular}{|c|c|c|}
\hline Species & Asia & $\begin{array}{r}\text { Eastern } \\
\text { China }\end{array}$ \\
\hline \multicolumn{3}{|l|}{$\mathrm{NO}_{\mathrm{x}}\left(\mathrm{Tg} \mathrm{N} \mathrm{yr}^{-1}\right)$} \\
\hline Aircraft & 0.08 & 0.02 \\
\hline Anthropogenic & 10.6 & 6.38 \\
\hline Biomass burning & 1.09 & 0.14 \\
\hline Biofuel & 0.02 & $<0.01$ \\
\hline Fertilizer & 0.35 & 0.12 \\
\hline Lightning & 1.16 & 0.28 \\
\hline Soil & 0.88 & 0.27 \\
\hline Total & 14.18 & 7.21 \\
\hline \multicolumn{3}{|l|}{$\mathrm{SO}_{2}\left(\mathrm{Tg} \mathrm{S} \mathrm{yr}^{-1}\right)$} \\
\hline Aircraft & 0.01 & $<0.01$ \\
\hline Anthrop & 23.85 & 15.98 \\
\hline Biomass bu & 0.36 & 0.04 \\
\hline Biofuel & $<0.01$ & $<0.01$ \\
\hline Volcanoes & 3.99 & 0.07 \\
\hline Ship & 0.48 & 0.05 \\
\hline Total & 28.69 & 16.14 \\
\hline \multicolumn{3}{|l|}{$\mathrm{NH}_{3}\left(\mathrm{Tg} \mathrm{N} \mathrm{yr}^{-1}\right)$} \\
\hline Anthro & 14.18 & 7.26 \\
\hline Natural & 2.33 & 0.49 \\
\hline Biomass burning & 0.82 & 0.11 \\
\hline Biofuel & 0.8 & 0.3 \\
\hline Total & 18.13 & 8.16 \\
\hline \multicolumn{3}{|l|}{ 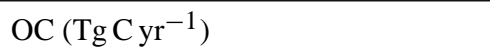 } \\
\hline Anthropc & 1.54 & 1.03 \\
\hline Biomass burning & 4.62 & 0.67 \\
\hline Biofuel & 3.47 & 1.44 \\
\hline Biogenic & 2.5 & 0.55 \\
\hline Total & 12.13 & 3.69 \\
\hline \multicolumn{3}{|l|}{$\mathrm{BC}\left(\mathrm{TgC} \mathrm{yr}^{-1}\right)$} \\
\hline Anth & 1.52 & 0.96 \\
\hline Biomass burning & 0.55 & 0.05 \\
\hline Biofuel & 0.92 & 0.39 \\
\hline Total & 2.99 & 1.4 \\
\hline
\end{tabular}

\section{Simulated IAVs of aerosols resulted from IAVs of meteorological parameters alone}

\subsection{Simulated distributions of aerosol concentrations}

Figure 2 shows simulated seasonal mean surface-layer concentrations of sulfate, nitrate, ammonium, $\mathrm{OC}, \mathrm{BC}$, and $\mathrm{PM}_{2.5}$ (sum of sulfate, nitrate, ammonium, $\mathrm{OC}$, and $\mathrm{BC}$ ) averaged over 2004-2012 of simulation ANNmet. The simulated aerosol concentrations were high over polluted eastern 


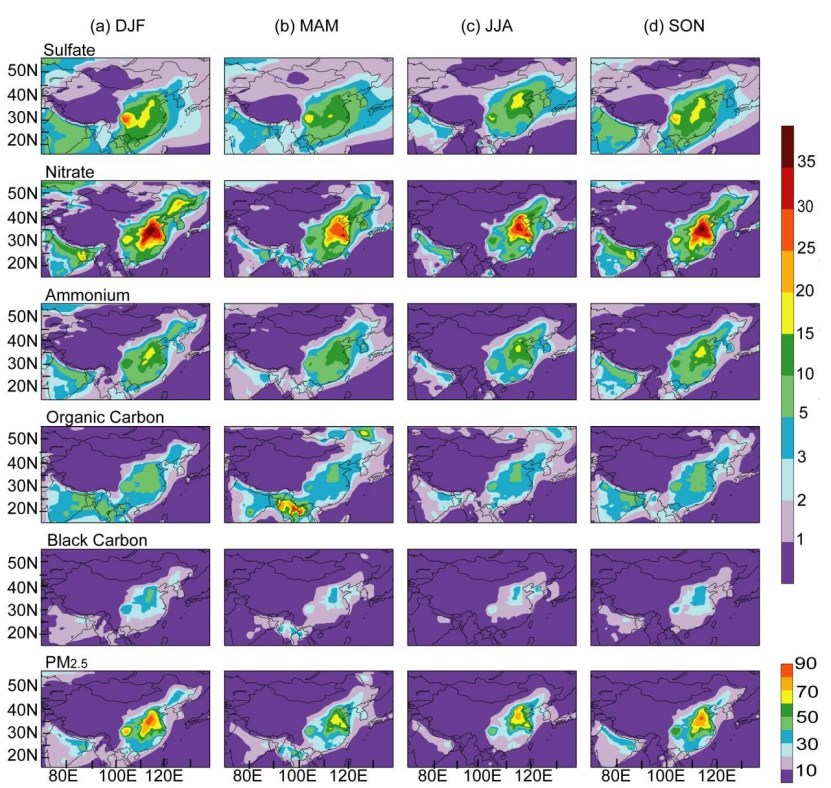

Figure 2. Simulated seasonal mean surface-layer concentrations $\left(\mu \mathrm{g} \mathrm{m}^{-3}\right)$ of sulfate, nitrate, ammonium, $\mathrm{OC}, \mathrm{BC}$, and $\mathrm{PM}_{2.5}$ in $\mathrm{AN}$ Nmet averaged over 2004-2012.

China throughout the year. Sulfate concentrations in NC were $15-20 \mu \mathrm{g} \mathrm{m}^{-3}$ in June-July-August (JJA) with the strong photochemistry in that season, and the concentrations over SC showed small values of $3-10 \mu \mathrm{g} \mathrm{m}^{-3}$ in JJA as a result of the large precipitation associated with the summer monsoon. The maximum sulfate concentrations of 25$30 \mathrm{\mu g} \mathrm{m}^{-3}$ were simulated over SCB in December-JanuaryFebruary (DJF), as a result of the large $\mathrm{SO}_{2}$ emissions from winter heating. Our simulated seasonal variations in sulfate concentrations agree well with those in Wang et al. (2013).

Simulated nitrate concentrations over NC were in the range of $15-40 \mathrm{\mu g} \mathrm{m}^{-3}$ throughout the year, with maximum concentrations of about $40 \mu \mathrm{g} \mathrm{m}^{-3}$ in DJF. High $\mathrm{NO}_{\mathrm{x}}$ emissions and low temperatures favored nitrate formation in DJF. Nitrate concentrations showed values of $5-15 \mu \mathrm{g} \mathrm{m}^{-3}$ over SC and SCB in JJA when temperatures were the highest. Simulated ammonium concentrations were in the range of 5$20 \mu \mathrm{g} \mathrm{m}^{-3}$ over $\mathrm{NC}, \mathrm{SC}$, and $\mathrm{SCB}$, with seasonal variations in these regions following those of nitrate.

The simulated distributions of $\mathrm{OC}$ and $\mathrm{BC}$ were similar to those of their emissions, with the highest values in NC. Simulated OC and BC concentrations were high in DJF and September-October-November (SON) and low in MarchApril-May (MAM) and JJA, owing to the seasonal variations in precipitation.

Simulated $\mathrm{PM}_{2.5}$ concentrations were in the range of 70 $90 \mu \mathrm{g} \mathrm{m}^{-3}$ in $\mathrm{NC}$ throughout the year, which were generally higher than the concentrations in SC and SCB. In the surface layer, nitrate was predicted to be the most abundant aerosol species over eastern China, followed by sulfate, ammonium,

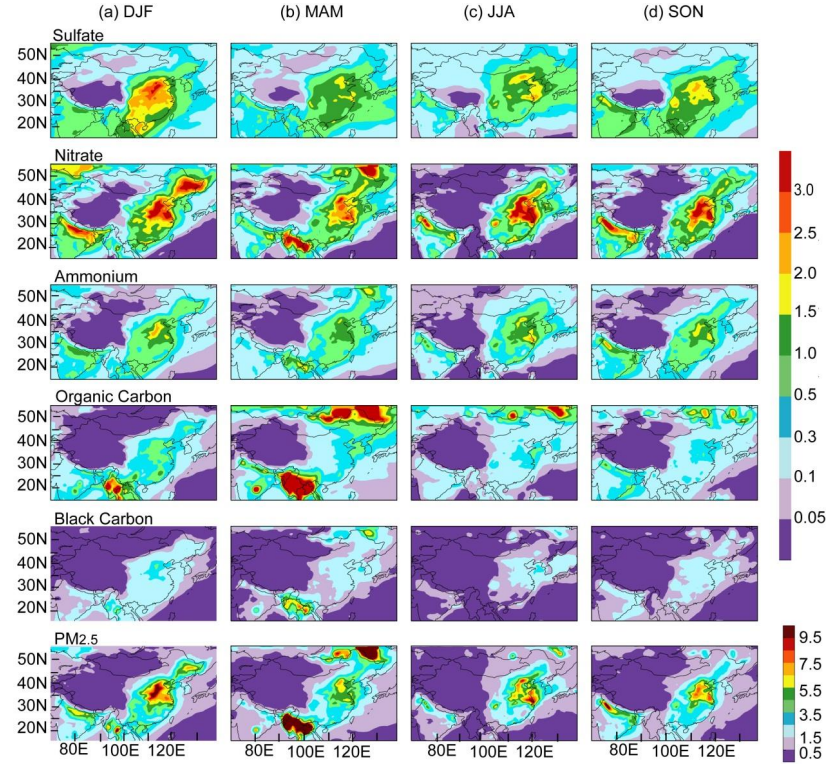

Figure 3. $\mathrm{MAD}\left(\mu \mathrm{g} \mathrm{m}^{-3}\right)$ of surface-layer concentrations of sulfate, nitrate, ammonium, $\mathrm{OC}, \mathrm{BC}$, and $\mathrm{PM}_{2.5}$ simulated in $\mathrm{ANNmet}$ for years 2004-2012.

OC, and BC. Wang et al. (2013) reported that high nitrate in the GEOS-Chem model is likely caused by the overestimate of $\mathrm{NH}_{3}$ emissions; and Kharol et al. (2013) demonstrated that the persistent nitrate in GEOS-Chem in China is, overall, as much linked to high $\mathrm{NO}_{\mathrm{x}}$ emissions as it is to high $\mathrm{NH}_{3}$ emissions.

\subsection{Simulated IAVs of aerosols}

Figures 3 and 4 show, respectively, the MAD and APDM values of seasonal mean surface-layer concentrations of sulfate, nitrate, ammonium, $\mathrm{OC}, \mathrm{BC}$, and $\mathrm{PM}_{2.5}$ simulated in $\mathrm{ANN}$ met. We also present the domain-averaged values of MAD and APDM for NC, SC, and SCB in Tables 2 and 3.

The MAD and APDM values of sulfate, nitrate, and ammonium from ANNmet indicated that concentrations of these species in NC had larger IAVs than those in SC (Tables 2, 3). Over NC, SC, and SCB, sulfate aerosol showed regional mean APDM values of 10-24\%. The largest IAVs of sulfate were found over NC in DJF, with APDM values exceeding $24 \%$. These IAVs were significant, considering that these were averages over 2004-2012; year by year variations can be larger than the averages reported here. Our simulated IAV of sulfate was close to the IAV of 14-20\% reported by Gong et al. (2010) for sulfate at the Canadian high Arctic.

The MAD and APDM values obtained in simulation ANNmet showed that nitrate concentrations also had large IAVs (Tables 2, 3). The APDM values were 13-18\% over NC where nitrate concentrations were the highest. The APDM values of nitrate in NC did not show large variations with season, which were larger than the APDM values of sulfate in 

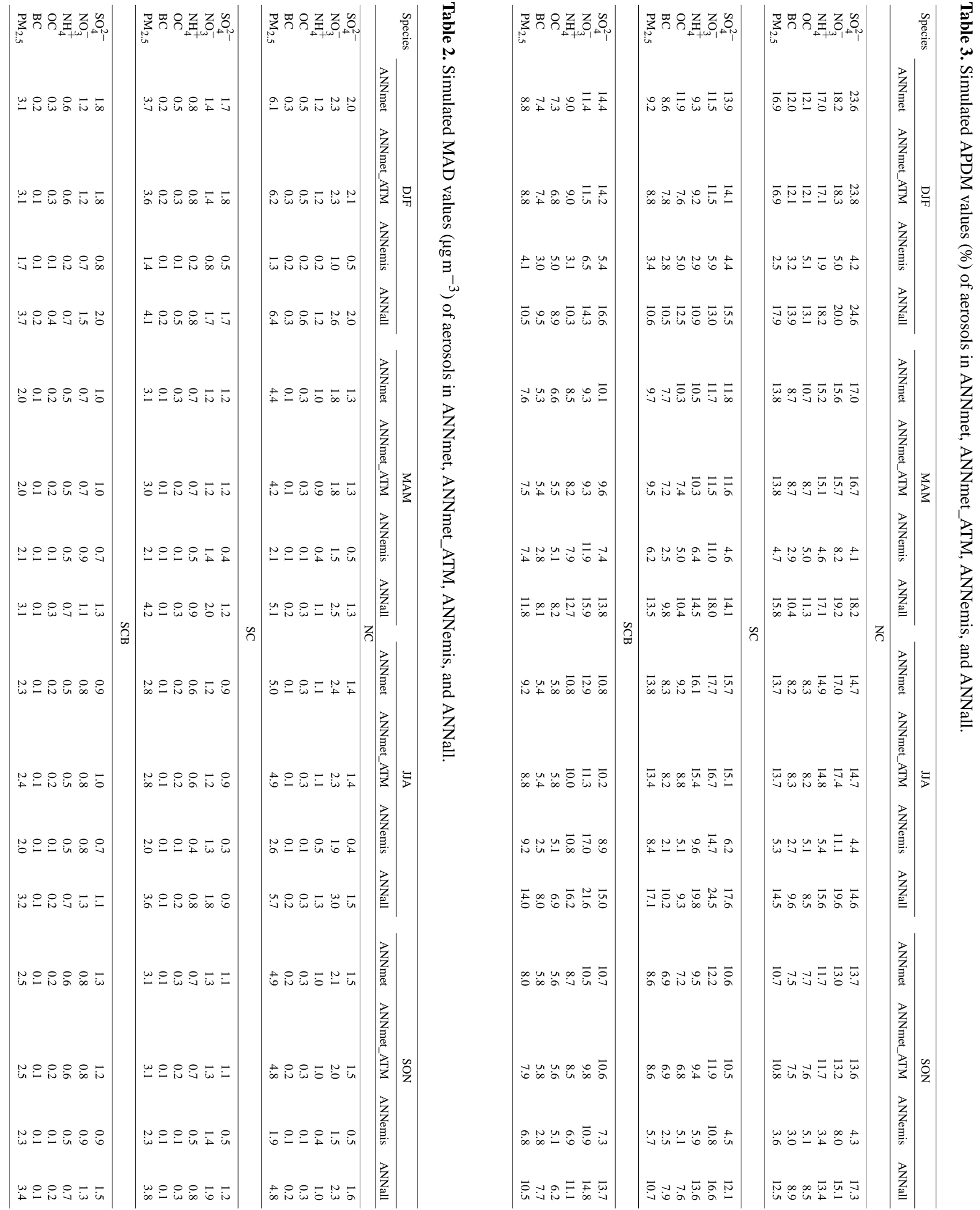


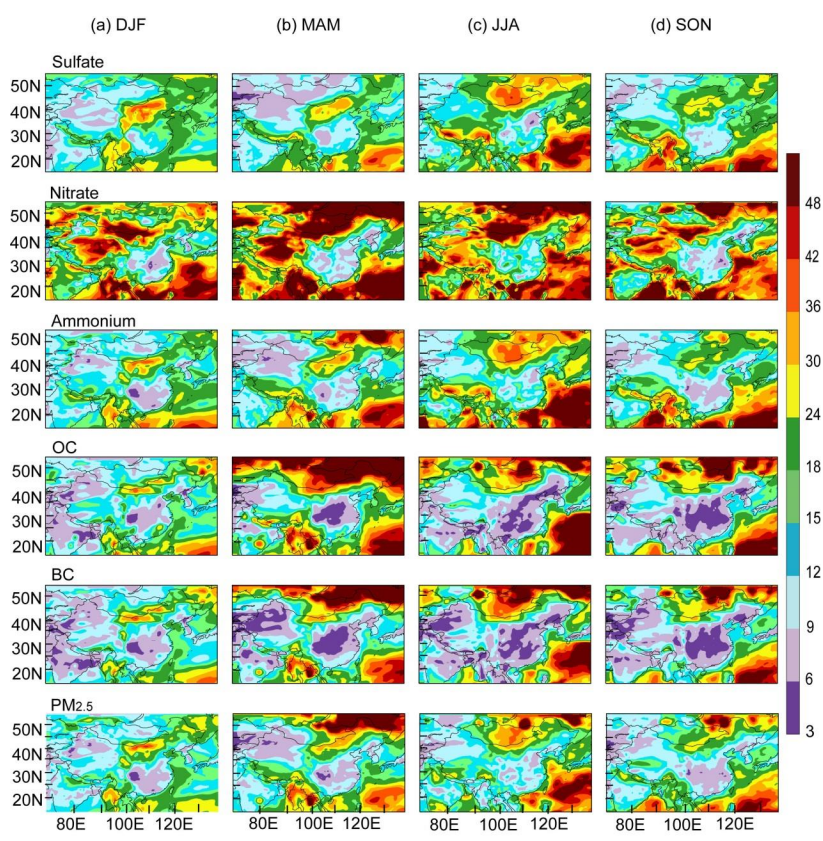

Figure 4. APDM (\%) of surface-layer concentrations of sulfate, nitrate, ammonium, $\mathrm{OC}, \mathrm{BC}$, and $\mathrm{PM}_{2.5}$ simulated in ANNmet for years 2004-2012.

JJA but smaller than those of sulfate in DJF. The distribution and magnitude of the APDM values of ammonium generally followed those of nitrate over polluted eastern China.

The spatial pattern of either MAD or APDM of OC was similar to that of $\mathrm{BC}$ in all seasons. OC exhibited seasonal mean APDM values of $6-12 \%$ in polluted $\mathrm{NC}$, SC, and SCB throughout the year. Because $\mathrm{BC}$ is a chemically inert tracer, the IAVs in BC obtained in ANNmet were caused by the variations in transport and deposition. The APDM values of BC were about the same as those of OC, except that the APDM values of $\mathrm{BC}$ were smaller in NC in MAM and in SC in DJF, MAM, and JJA.

The IAVs of $\mathrm{PM}_{2.5}$ concentrations were the largest in NC; the regional mean APDM values were 17, 14, 14, and $11 \%$ in DJF, MAM, JJA, and SON (Table 3), respectively. Over SC, the maximum APDM value of $14 \%$ was found in JJA and the highest APDM values were about $9 \%$ in the other seasons (Table 3). Over SCB, $\mathrm{PM}_{2.5}$ showed the smallest IAVs among all regions, with APDM values of $8-9 \%$ in all seasons.

\subsection{Comparisons of simulated IAVs of aerosols with measurements}

Simulated concentrations of sulfate, nitrate, and ammonium aerosols in China have been evaluated in the study of Wang et al. (2013) and those of carbonaceous aerosols in China have been evaluated by Fu et al. (2012), both of which used the same one-way nested-grid capability of the GEOS-Chem.
Wang et al. (2013) found that simulated concentrations of sulfate, nitrate and ammonium at 22 sites in East Asia exhibited annual mean biases of $-10,+31$, and $+35 \%$, respectively; and Fu et al. (2012) showed that the simulated annual mean concentrations of $\mathrm{BC}$ and $\mathrm{OC}$ averaged over rural and background sites were underestimated by 56 and $76 \%$, respectively.

For the purpose of this study, we evaluated the model's performance in simulating the IAVs of aerosols by comparing simulated AODs with satellite measurements, because of the lack of long-term ground-based measurements in China (Chan and Yao, 2008). The Level 3 MODIS/Terra monthly products (MOD08_M3; http://ladsweb.nascom. nasa.gov/) with $1^{\circ} \times 1^{\circ}$ equal-angle global grid were obtained from NASA's LAADS (Level 1 and Atmosphere Archive and Distribution System). Collections 5 and 5.1 contain the time series of AODs from March 2000 to the present. We used AODs at the $550 \mathrm{~nm}$ wavelength, which incorporated only the highest quality retrievals. Over East Asia, the MODIS measurements have been well validated through many studies (Chin et al., 2004; Park et al., 2011). In the GEOS-Chem model, the AODs of sulfate, nitrate, ammonium, OC, BC, sea salt, and dust aerosols were calculated based on aerosol mass concentration, extinction efficiency, effective radius, particle mass density, and the assumed aerosol size distribution (Drury et al., 2010). The hygroscopic growth of each aerosol species with relative humidity was accounted for, using the hygroscopic growth factors listed in Martin et al. (2003).

We compared simulated and observed IAVs in AODs for the cities of Beijing $\left(39.5^{\circ} \mathrm{N}, 116.2^{\circ} \mathrm{E}\right)$, Changsha $\left(28.1^{\circ} \mathrm{N}\right.$, $112.6^{\circ} \mathrm{E}$ ) and Chengdu (30.7 $\left.\mathrm{N}, 104.0^{\circ} \mathrm{E}\right)$ (Fig. 5), which were chosen to represent the model performance in the $\mathrm{NC}$, SC and SCB regions, respectively. The correlation coefficients between observed and modeled monthly mean AODs from ANNmet simulations were 0.83, 0.34, and 0.13 for Beijing, Changsha, and Chengdu, respectively. The large correlation coefficient for Beijing indicates that the model was able to capture to some extent the observed IAVs in NC. The small correlation coefficients in Chengdu can be explained in part by the complex topography and satellite limitations such as cloud contamination (Xia et al., 2004). Note that in simulation ANNmet, simulated AODs correlated well with the simulated column burdens and surfacelayer concentrations of $\mathrm{PM}_{2.5}$; the correlation coefficients between simulated monthly mean AODs and column burdens (surface-layer concentrations) of $\mathrm{PM}_{2.5}$ were 0.95 (0.81), 0.94 (0.81), and 0.91 (0.77) over Beijing, Changsha, and Chengdu, respectively. The IAVs of observed AODs agreed fairly well with the IAVs of surface-layer aerosol concentrations. For example, the seasonal mean APDM values of observed AODs were 18 (DJF), 15 (MAM), 24 (JJA), and $16 \%$ (SON) for Beijing, close to the seasonal mean APDM values of surface-layer $\mathrm{PM}_{2.5}$ shown in Fig. 4. 

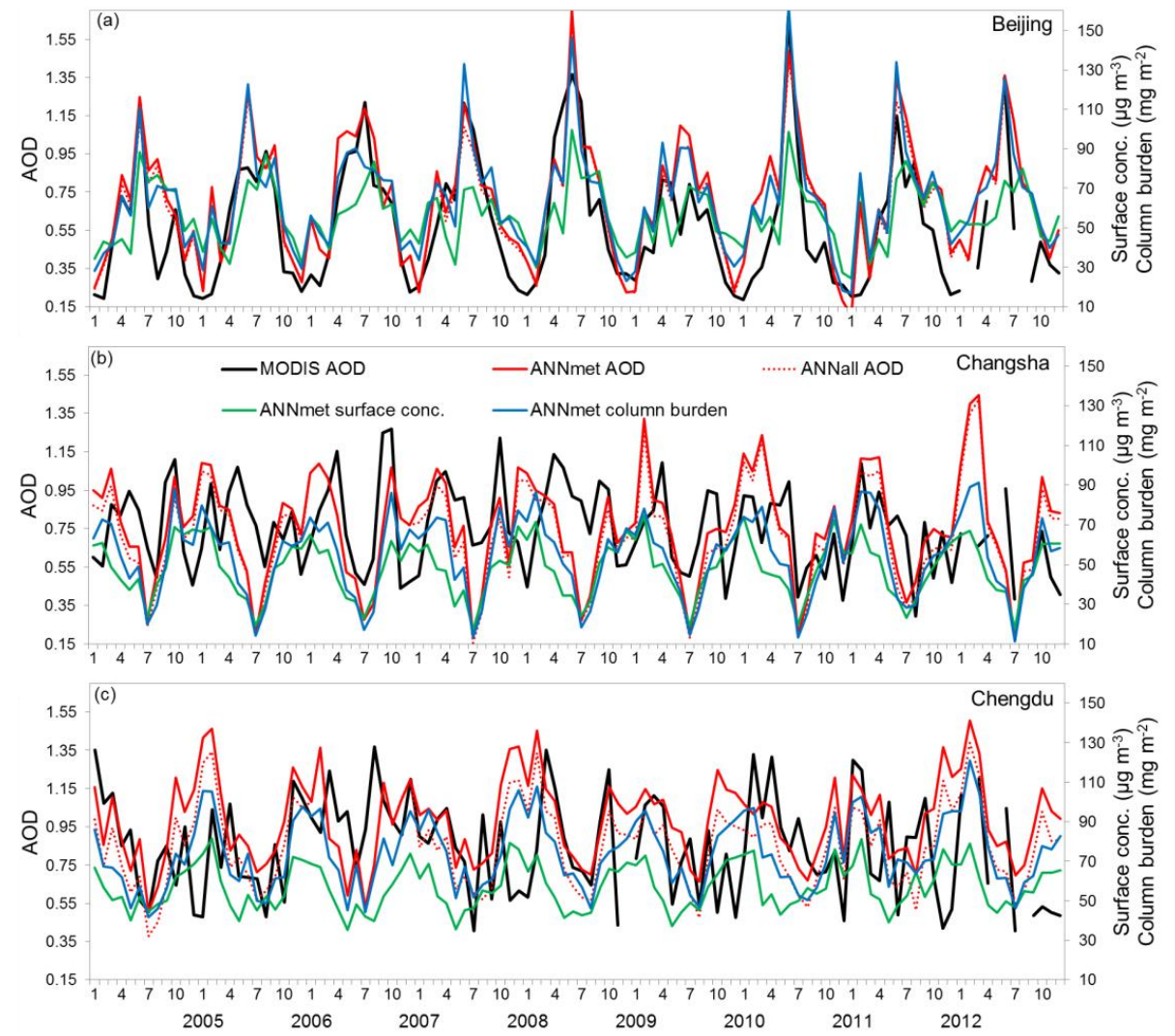

Figure 5. MODIS AOD (black line, left axis), simulated AOD in ANNall (red dotted line, left axis), simulated AOD in ANNmet (red line, left axis), simulated surface-layer $\mathrm{PM}_{2.5}$ concentrations in ANNmet (green line, $\mu \mathrm{g} \mathrm{m}^{-3}$, right axis), and simulated column burden of $\mathrm{PM}_{2.5}$ in ANNmet (blue line, $\mathrm{mg} \mathrm{m}^{-2}$, right axis) over polluted cities of (a) Beijing, (b) Changsha, and (c) Chengdu.

\section{Understanding the IAVs of aerosols by process analyses}

\subsection{IAVs of meteorological parameters}

Figure 6 shows seasonal mean temperature, specific humidity, precipitation, $850 \mathrm{hPa}$ zonal and meridional winds for DJF and JJA. All these meteorological fields were averaged over years 2004-2012. Over central and eastern China, temperature, specific humidity and precipitation generally exhibited much larger values in JJA than in DJF. At $850 \mathrm{hPa}$, strong westerlies were found in NC in DJF, and prevailing southerlies occurred in JJA, reflecting the typical features of winds in China.

Figures 7 and 8 show, respectively, the MAD and APDM values of surface-layer temperature, specific humidity, and precipitation for DJF and JJA. The APDM values of temperature in DJF were generally larger than those in JJA. Piao et al. (2003) also showed that the largest IAV of temperature in eastern China was in winter (December and February) based on the reanalyzed temperatures over 1982-1999. Specific humidity showed APDM values of 6-20\% in DJF and of 2$8 \%$ in JJA over central and eastern China. For precipitation, APDM values of $20-80 \%$ and $10-30 \%$ were calculated in
DJF and JJA, respectively, and the APDM values of precipitation were larger in $\mathrm{NC}$ than in $\mathrm{SC}$, which agreed with those reported in Qian and Lin (2005). The variations in temperature and specific humidity can influence chemical reactions of sulfate, nitrate and ammonium, while those in precipitation are important for wet deposition of all aerosol species. The relatively large APDM values of these meteorological parameters in DJF suggested large IAVs of aerosols in this season.

\subsection{Process analyses}

The concentrations of aerosols are determined by emissions, chemical reactions, transport, and deposition. Therefore, the IAVs of aerosols are influenced by the IAV of each of these processes. The weighted contribution of each process to IAV of an aerosol is estimated here using

$\% \mathrm{PC}_{i}=\mathrm{MAD}_{i} / \sum_{i}^{n} \mathrm{MAD}_{i}$,

where $n$ is the number of processes considered, $\mathrm{MAD}_{i}$ is the MAD value of process $i$ and $\% \mathrm{PC}_{i}$ is the relative contribution of process $i$ to the sum of the contributions from all processes (Im et al., 2011). Once the most important processes are selected from this approach, meteorological variables to 
DJF
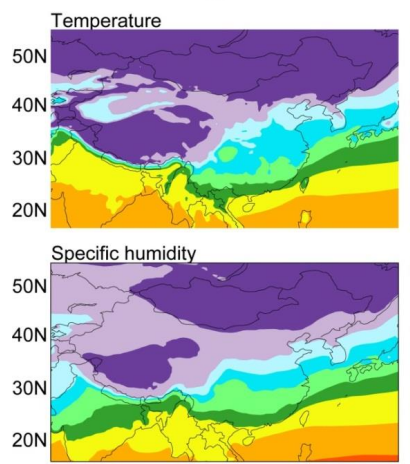

Precipitation
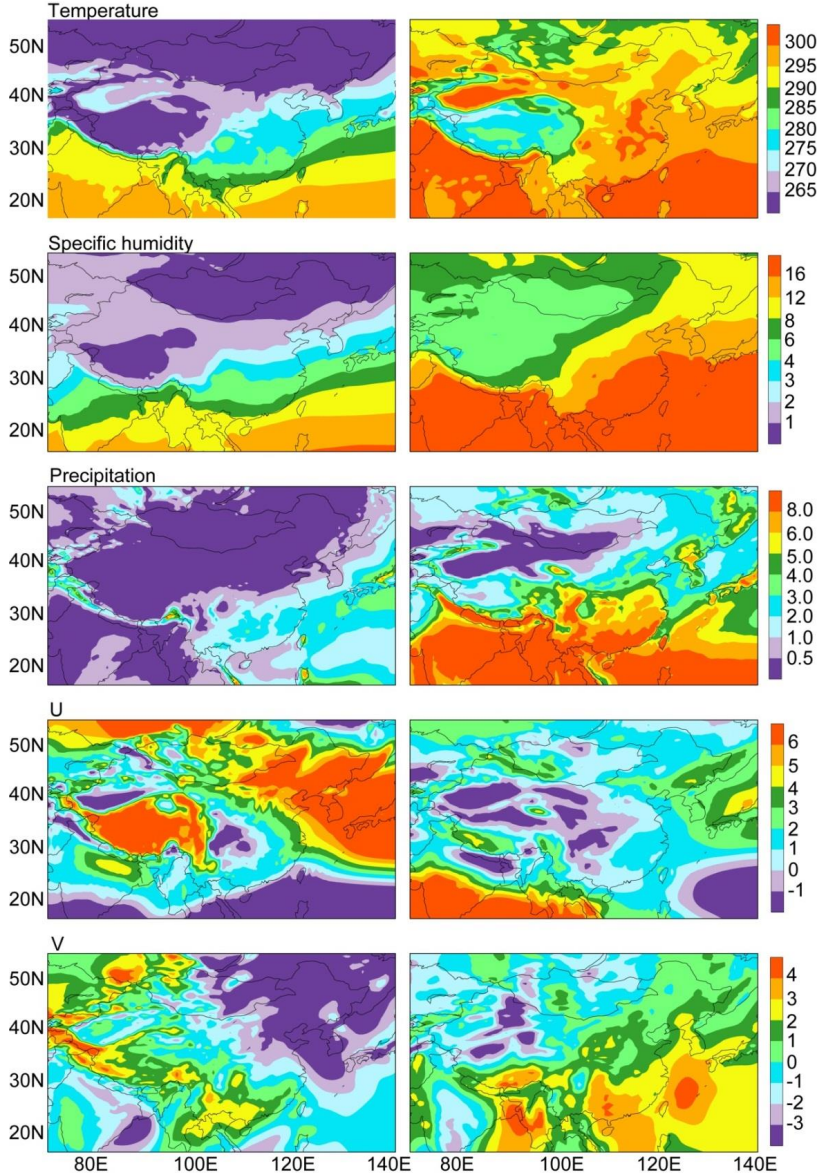

Figure 6. Seasonal mean surface air temperature $(\mathrm{K})$, specific humidity $\left(\mathrm{g} \mathrm{kg}^{-1}\right)$, precipitation $\left(\mathrm{mm} \mathrm{d}^{-1}\right)$, zonal and meridional wind at $850 \mathrm{hPa}\left(\mathrm{m} \mathrm{s}^{-1}\right)$ in DJF and JJA. Winds that were eastward or northward were positive, and those that were westward and southward were negative. Meteorological fields were from the GEOS-5 assimilated meteorological data and were averaged over 2004-2012.

which the processes are sensitive to are classified as the key meteorological parameters that lead to IAV of the aerosol. Since we aimed to examine the IAVs in surface-layer aerosol concentrations, our process analyses for an aerosol species were performed for each region (NC, SC, or SCB) from the surface to $1 \mathrm{~km}$ altitude. For an aerosol species, the budget (mass flux from each process) was constructed for the selected region considering the mass balance of this aerosol. Chemical production and removal, transport, as well as wet and dry deposition of the aerosol were diagnosed at every time step and summed over each season in simulation ANNmet.

\subsubsection{Sulfate}

Processes that influence the IAVs of sulfate concentrations include anthropogenic emissions, formation pathways (gas-
DJF
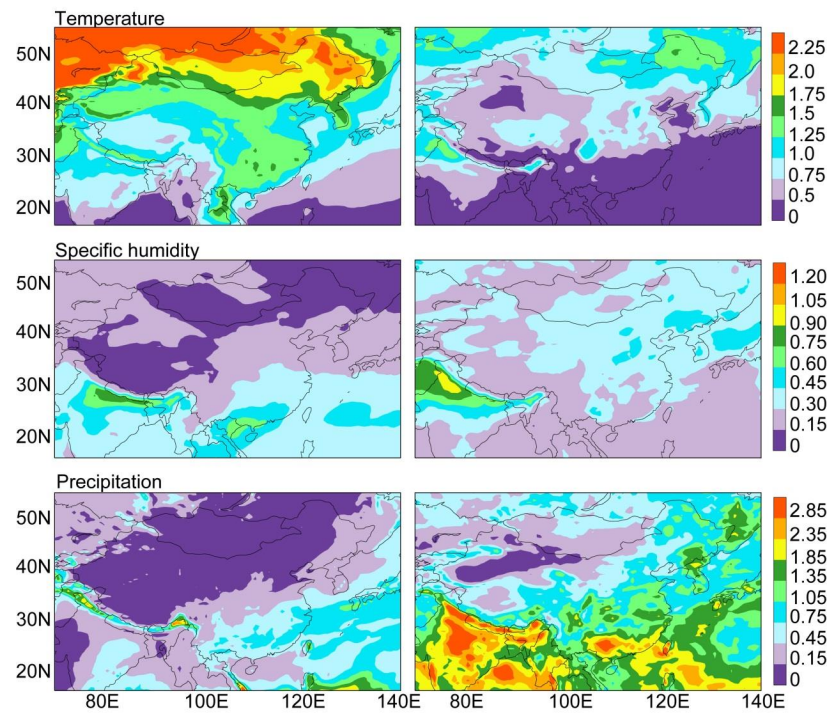

Figure 7. The MAD values of surface air temperature (K), specific humidity $\left(\mathrm{g} \mathrm{kg}^{-1}\right)$ and precipitation $\left(\mathrm{mm} \mathrm{d}^{-1}\right)$ in DJF and JJA based on the GEOS-5 assimilated meteorological fields of 20042012.
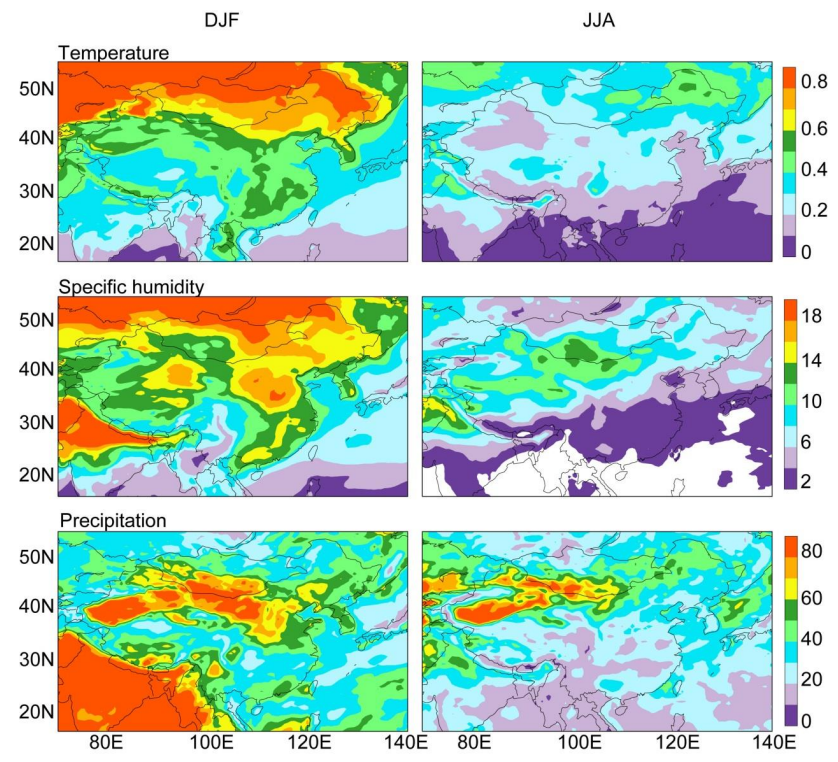

Figure 8. The APDM values (\%) of surface air temperature, specific humidity, and precipitation in DJF and JJA based on the GEOS-5 assimilated meteorological fields of 2004-2012.

phase oxidation of $\mathrm{SO}_{2}$ by $\mathrm{OH}$, and in-cloud oxidation of $\mathrm{SO}_{2}$ by ozone and hydrogen peroxide), mass fluxes through the four lateral boundaries and the upper boundary at $1 \mathrm{~km}$, wet and dry deposition. On the basis of simulation ANNmet, Fig. 9 shows the mass fluxes and APDM values and Fig. 10 shows the MAD values and relative contributions of individual atmospheric processes to sulfate concentrations in 
different regions for DJF and JJA. Transport fluxes were calculated at the boundaries while other sources and sinks were the sums over the grid cells of the region under $1 \mathrm{~km}$.

With respect to the sulfate budget over NC in DJF, vertical flux through the top side and gas-phase sulfate formation by reaction of $\mathrm{SO}_{2}$ with $\mathrm{OH}$ had the largest values of 0.041 and $0.019 \mathrm{Tg} \mathrm{S}$ season $^{-1}$, respectively (Fig. 9a). Among the four horizontal fluxes through the lateral boundaries of $\mathrm{NC}$, the flux through the south boundary had the largest value of $0.017 \mathrm{Tg} \mathrm{S}$ season $^{-1}$, while that through the west boundary had the smallest value of $0.003 \mathrm{Tg} \mathrm{S}$ season $^{-1}$. The in-cloud reactions of $\mathrm{SO}_{2}$ with $\mathrm{O}_{3}$ and $\mathrm{H}_{2} \mathrm{O}_{2}$ contributed relatively little to sulfate formation, by 0.005 and $0.004 \mathrm{Tg} \mathrm{S}_{\mathrm{Season}}{ }^{-1}$, respectively. Wet deposition was $0.006 \mathrm{Tg} \mathrm{S}_{\mathrm{Season}}{ }^{-1}$ and dry deposition was the smallest flux. Figure 10 shows that gas-phase oxidation of $\mathrm{SO}_{2}$ by $\mathrm{OH}$ was the most important process that contributed to the IAV of sulfate, with a relative contribution of $30 \%$, followed by the vertical flux through the top side $(18 \%)$. The relative contributions of horizontal fluxes through the lateral boundaries were in the range of $3-11 \%$. Each of the aqueous-phase oxidations of $\mathrm{SO}_{2}$ by $\mathrm{O}_{3}$ and $\mathrm{H}_{2} \mathrm{O}_{2}$ accounted for $6 \%$ of the IAV of sulfate. The relative contribution by wet deposition was $8 \%$ and that by dry deposition was $0.4 \%$ (Fig. 10a). In JJA, the gas-phase formation of sulfate increased to $0.039 \mathrm{Tg} \mathrm{S}$ season $^{-1}$ with a relative contribution of $57 \%$, making it the only process that determined the IAV of sulfate concentration over $\mathrm{NC}$ in this season. Since gas-phase oxidation of $\mathrm{SO}_{2}$ is sensitive to temperature and humidity (Yao et al., 2002; Zhang et al., 2012), we conclude that the variations in temperature and specific humidity were the key factors that drove the IAV of sulfate over NC. The relatively high MAD values of temperature in $\mathrm{NC}$ in both DJF and JJA (Fig. 7) as well as the large MAD values of specific humidity over NC in JJA (Fig. 7) support the above conclusion.

Similar analyses were performed for sulfate in SC. In DJF, the gas-phase formation of sulfate and wet deposition were the dominant source and sink of sulfate in this region (Fig. 9b). The vertical flux, flux through the south boundary, and wet deposition had the largest contributions to IAV of sulfate with relative contributions of 24,18 , and $15 \%$, respectively, indicating that wind and precipitation were the main meteorological factors that determined the IAV of sulfate concentration over SC in DJF. In JJA, sulfate formation from the reaction of $\mathrm{SO}_{2}$ with $\mathrm{OH}$ had a large value of $0.030 \mathrm{Tg} \mathrm{S}$ season $^{-1}$, but this process had a very low APDM value of $6 \%$ (Fig. 9b). Figure 10b showed that wet deposition and in-cloud oxidation of $\mathrm{SO}_{2}$ by $\mathrm{H}_{2} \mathrm{O}_{2}$ were the prevailing processes that contributed, respectively, 20 and $18 \%$ to the IAV of sulfate concentration in SC. These two processes corresponded well with the high MAD values of precipitation in JJA as shown in Fig. 7.

With respect to the sulfate budget over the SCB in DJF, vertical flux through the top side, wet deposition, and gasphase formation of sulfate had the largest values of 0.050 , (a)

$\begin{array}{lll}-\mathrm{DJF} & -\mathrm{JJA}\end{array}$

9080706050403020100

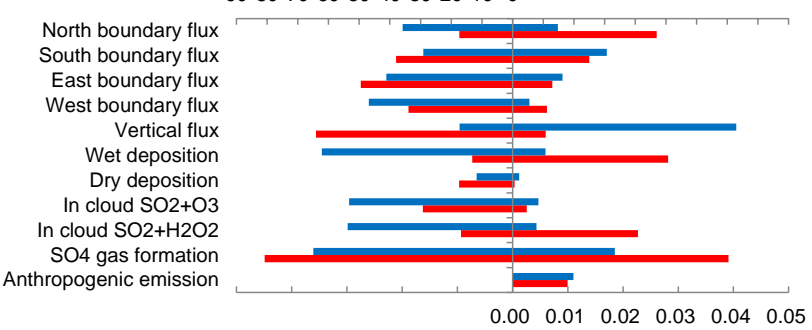

(b) 9080706050403020100

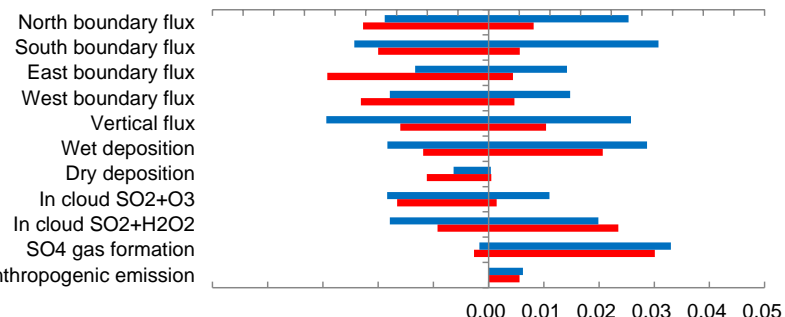

(c) 9080706050403020100

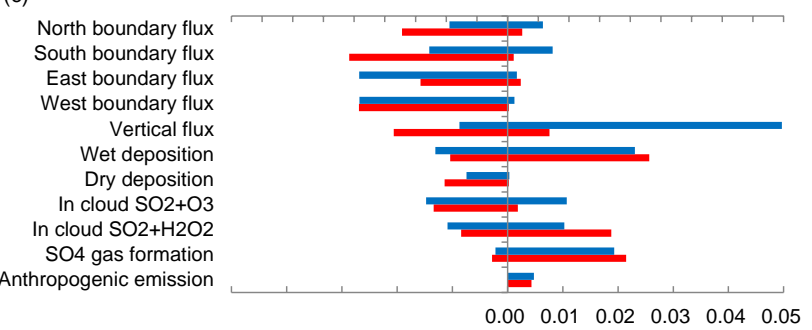

Figure 9. Sulfate budget (mass flux from each process in $\mathrm{Tg} \mathrm{S}$ season $^{-1}$, right) and APDM of each flux (\%, left) in (a) NC, (b) SC, and (c) SCB obtained from simulation ANNmet. Blue lines are for DJF and red lines are for JJA. Transport fluxes were calculated at the boundaries while other sources and sinks were calculated as the sums over the grid cells of the region under $1 \mathrm{~km}$.

0.023, and $0.019 \mathrm{Tg} \mathrm{S}_{\text {season }}{ }^{-1}$, respectively (Fig. 9c). The vertical flux through the top side was the most important process that contributed to the IAV of sulfate with a relative contribution of $33 \%$, followed by wet deposition (23\%) and incloud oxidation of $\mathrm{SO}_{2}$ by $\mathrm{O}_{3}(12 \%)$ (Fig. 10c). We can infer from these analyses that wind (or convergence of winds) was the dominant meteorological factor to influence IAV of sulfate over SCB in DJF. In JJA, wet deposition was the largest contributor to the IAV of sulfate concentration with a relative contribution of $35 \%$, which corresponded well with the high MAD values of precipitation in JJA (Fig. 7).

\subsubsection{Nitrate}

The processes that influence nitrate concentration include gas-to-aerosol conversion of $\mathrm{HNO}_{3}$ to form nitrate, mass fluxes through the four lateral boundaries and the upper boundary at $1 \mathrm{~km}$, wet and dry deposition (Fig. 11). Among all the processes, gas-to-aerosol conversion was found to be 

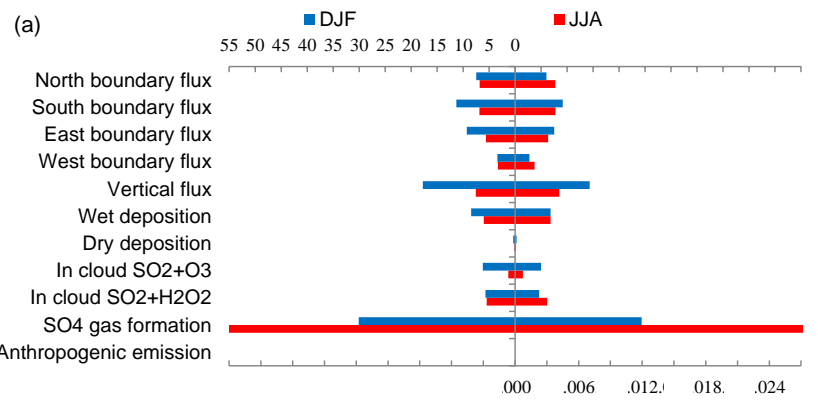

(b)

North boundary flux South boundary flux East boundary flux West boundary flux Vertical flux Wet deposition Dry deposition In cloud $\mathrm{SO} 2+\mathrm{O} 3$ In cloud $\mathrm{SO} 2+\mathrm{H} 2 \mathrm{O} 2$ $\mathrm{SO} 4$ gas formation Anthropogenic emission

5550454035302520151050

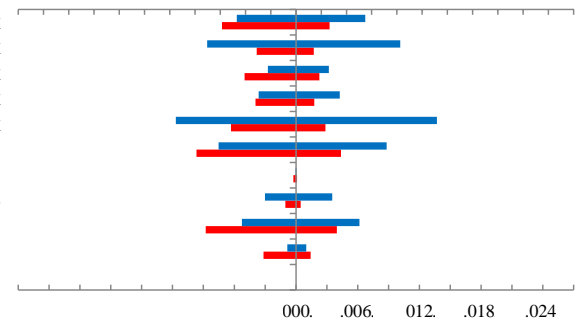

(c)

North boundary flux South boundary flux East boundary flux West boundary flux Vertical flux Wet deposition Dry deposition In cloud $\mathrm{SO} 2+\mathrm{O} 3$ in cloud $\mathrm{SO} 2+\mathrm{H} 2 \mathrm{O} 2$ $\mathrm{SO} 4$ gas formation Anthropogenic emission 5550454035302520151050

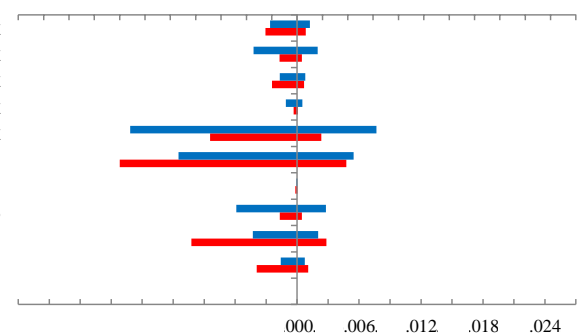

Figure 10. The MAD (Tg S season ${ }^{-1}$, right) and relative contribution ( $\%$, left) of each sulfate process (flux) in (a) NC, (b) SC, and (c) SCB obtained from simulation ANNmet. Blue lines are for DJF and red lines are for JJA. Transport fluxes were calculated at the boundaries while other sources and sinks were calculated as the sums over the grid cells of the region under $1 \mathrm{~km}$.

the key process that drove the IAV of nitrate over the three studied regions. In DJF (JJA), gas-to-aerosol conversion was calculated to have relative contributions of 56 (71), 45 (73), and $62 \%(73 \%)$ in NC, SC, and SCB, respectively (Fig. 12), indicating that the IAVs in temperature and specific humidity drove the IAVs of nitrate in these polluted regions. As reported by Dawson et al. (2007), temperature and humidity have the largest influences on gas-to-aerosol partitioning of $\mathrm{HNO}_{3}$.

\subsubsection{Organic carbon}

Processes that influence IAV of OC include mass fluxes through the four lateral boundaries and the upper boundary, emissions from anthropogenic, biomass, biofuel and biogenic sources, as well as wet and dry deposition. With respect to the OC budget over NC, emissions had the largest mass fluxes in the OC budget in both DJF and JJA (Fig. 13). However, Fig. 14 shows that transport fluxes were the most (a)

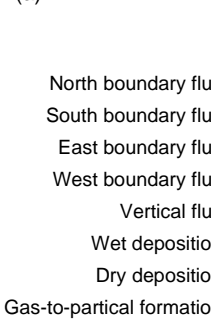
$\square \mathrm{DJF}$
$\because J J A$

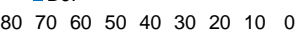

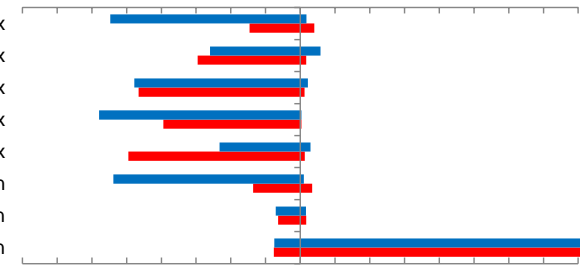

.00 .05 .10 .15 .20 .25 .30 .35 .40

(b)

$\begin{array}{lllllllll}80 & 70 & 60 & 50 & 40 & 30 & 20 & 10 & 0\end{array}$

North boundary flux

South boundary flux

East boundary flux

West boundary flux

Vertical flux

Wet deposition

Dry deposition

Gas-to-partical formation

(c)

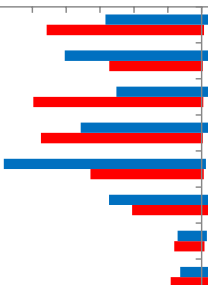

.00 .05 .10 .15 .20 .25 .30 .35 .40

$807060 \quad 50 \quad 40 \quad 30 \quad 20 \quad 10 \quad 0$

North boundary flux

South boundary flux

East boundary flux

West boundary flux

Vertical flux

Wet deposition

Dry deposition

Gas-to-partical formation

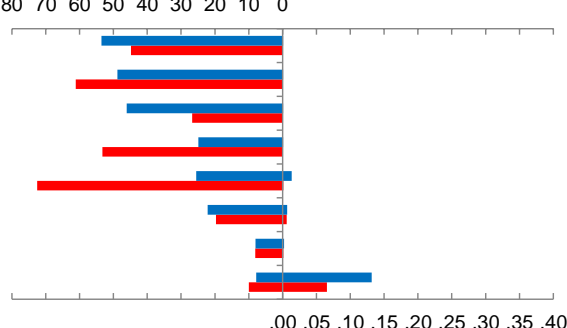

Figure 11. Nitrate budget (mass flux from each process in $\mathrm{Tg} \mathrm{N}$ season $^{-1}$, right) and APDM of each flux (\%, left) in (a) NC, (b) SC, and (c) SCB obtained from simulation ANNmet. Blue lines are for DJF and red lines are for JJA. Transport fluxes were calculated at the boundaries while other sources and sinks were calculated as the sums over the grid cells of the region under $1 \mathrm{~km}$.

important processes to drive the IAV of OC in both seasons. The relative contributions of transport fluxes were in the range of $5-23 \%$ in DJF and $8.0-25 \%$ in JJA. Wet deposition made contributions of $9 \%$ in DJF and $11 \%$ in JJA. Note that the relative contributions of biogenic and biomass emissions were very small.

A similar analysis for SC showed that biofuel emission, fluxes through the north and south boundaries had the largest values in the OC budget in DJF (Fig. 13). Vertical transport, transport through the south boundary, and flux through the north boundary had the largest contributions to the IAV of OC in DJF, with relative contributions of 24,20 , and $15 \%$, respectively (Fig. 14). In JJA, transport through the north boundary had the largest relative contribution of $23 \%$, followed by wet deposition of $16 \%$.

Over SCB in DJF, vertical transport had the largest relative contribution of $31 \%$, followed by mass flux through the south boundary of $24 \%$ (Fig. 14). In JJA, wet deposition, vertical transport, and transport at the south boundary had 
(a)

$$
\text { -DJF } \quad \text { JJA }
$$

$\begin{array}{llllllll}75 & 65 & 55 & 45 & 35 & 25 & 15 & 5\end{array}$

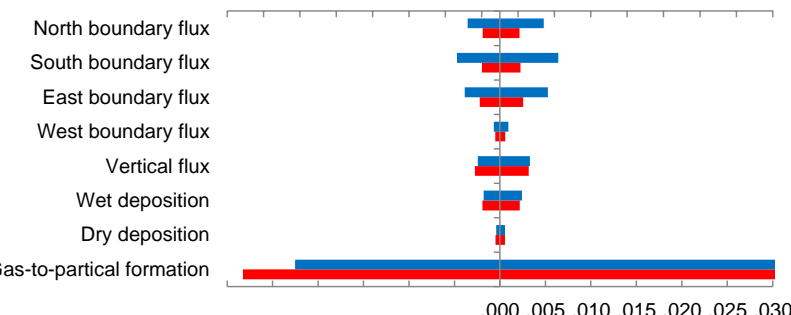

(b) North boundary flux
South boundary flux
East boundary flux
West boundary flux
Vertical flux
Wet deposition
Dry deposition
Gas-to-partical formation $\begin{array}{llllllll}75 & 65 & 55 & 45 & 35 & 25 & 15 & 5\end{array}$

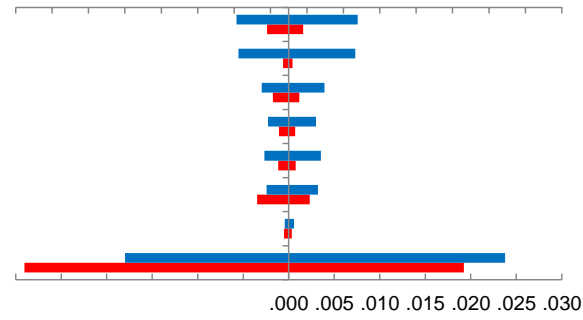

(c) $\begin{array}{llllllll}75 & 65 & 55 & 45 & 35 & 25 & 15 & 5\end{array}$

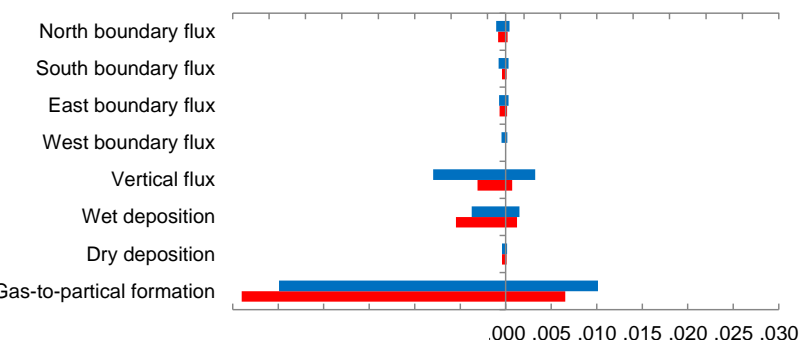

Figure 12. The MAD (Tg N season ${ }^{-1}$, right) and relative contribution (\%, left) of each nitrate process (flux) in (a) $\mathrm{NC}$, (b) SC, and (c) SCB obtained from simulation ANNmet. Blue lines are for DJF and red lines are for JJA. Transport fluxes were calculated at the boundaries while other sources and sinks were calculated as the sums over the grid cells of the region under $1 \mathrm{~km}$.

the largest contributions to the IAV of OC, with relative contributions of 30,15 , and $11 \%$, respectively.

To conclude, wind was the most important meteorological parameter that drove the IAV of OC in the three regions. Precipitation also played a crucial role in JJA over SC and SCB.

\section{Impacts of anthropogenic emissions and meteorology- sensitive natural emissions on IAVs of aerosols}

Table 2 and 3 show, respectively, the simulated MAD and APDM values of $\mathrm{SO}_{4}^{2-}, \mathrm{NO}_{3}^{-}, \mathrm{NH}_{4}^{+}, \mathrm{OC}, \mathrm{BC}$, and $\mathrm{PM}_{2.5}$ in ANNmet, ANNmet_ATM, ANNemis, and ANNall experiments. As described in Sect. 2, the comparisons of the APDM values from ANNemis with those obtained in ANNmet indicate the relative importance of anthropogenic emissions and meteorological parameters in the IAVs of aerosols. Based on the annual scaling factors taken from Zhang et (a)
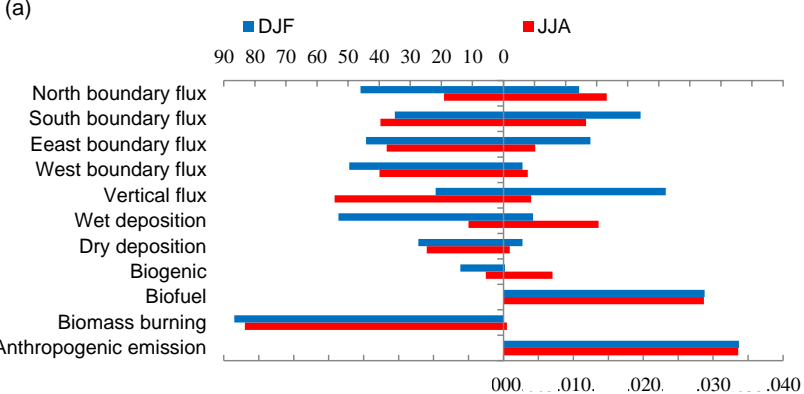

(b) $90 \quad 8070 \quad 605040 \quad 3020 \quad 10 \quad 0$

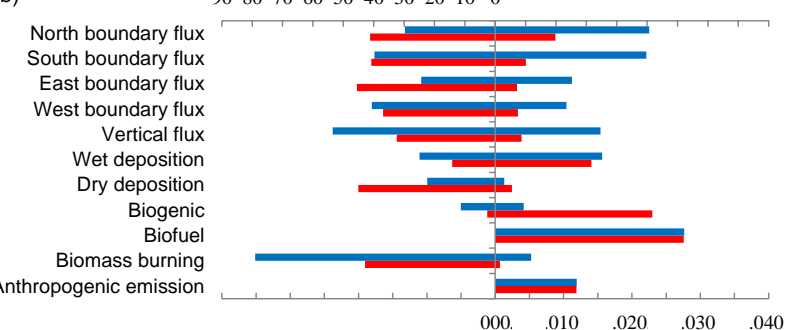

(c)

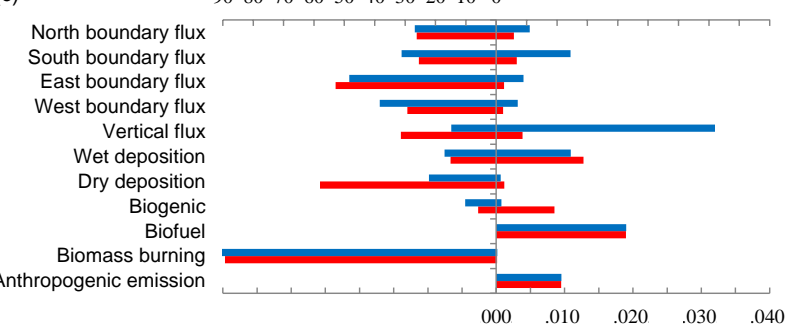

Figure 13. Organic carbon budget (mass flux from each process in $\mathrm{TgC}$ season $^{-1}$, right) and APDM of each flux (\%, left) in (a) $\mathrm{NC}$, (b) SC, and (c) SCB obtained from simulation ANNmet. Blue lines are for DJF and red lines are for JJA. Transport fluxes were calculated at the boundaries while other sources and sinks were calculated as the sums over the grid cells of the region under $1 \mathrm{~km}$.

al. (2012) and $\mathrm{Lu}$ et al. (2011), the annual total emissions of $\mathrm{NO}_{\mathrm{x}}, \mathrm{SO}_{2}, \mathrm{OC}$, and $\mathrm{BC}$ in China had APDM values of $7,5,3$, and 5\%, respectively, over years 2004-2012. In NC, the APDM values of concentrations of all aerosol species obtained in ANNemis were much smaller than those in ANNmet, indicating that the variations in meteorological parameters played more important roles than variations in anthropogenic emissions in driving the IAVs of aerosols. Similar results were found in SC, except that the APDM values of nitrate aerosol driven by variations in emissions alone became close to those driven by variations in meteorological parameters alone. In SCB, the variations in emissions were as important as those in meteorological fields for IAVs of nitrate, ammonium, and $\mathrm{PM}_{2.5}$ aerosols in MAM, JJA, and SON. These results in SCB can be explained by the nonlinear responses in nitrate and ammonium aerosols to variations in precursor emissions. Wang et al. (2013) also showed that nonlinear responses of sulfate, nitrate and ammonium to changes in precursor emissions differed by region and 
(a)

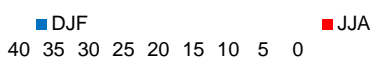

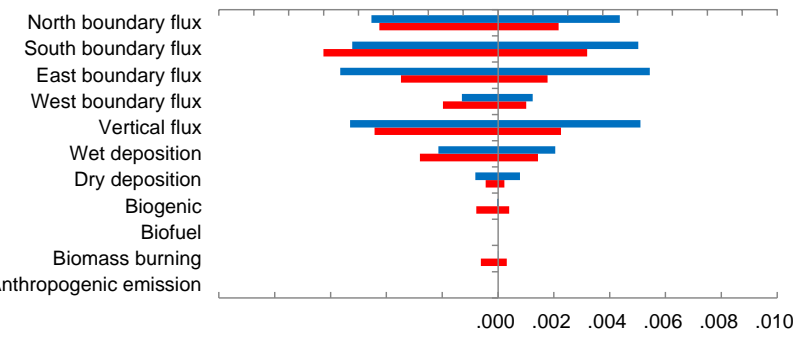

(b) $\begin{array}{lllllllll}40 & 35 & 30 & 25 & 20 & 15 & 10 & 5 & 0\end{array}$

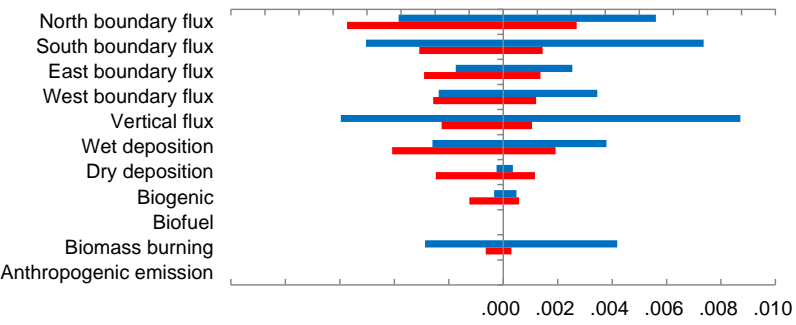

(c) $40 \quad 3530252015 \quad 10 \quad 5 \quad 0$

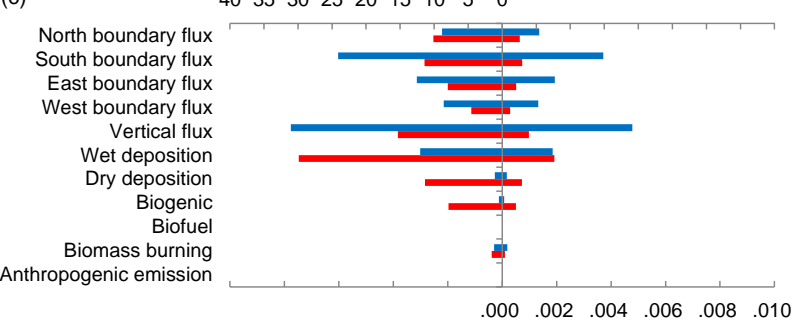

Figure 14. The MAD (Tg $\mathrm{Cseason}^{-1}$, right) and relative contribution (\%, left) of each organic carbon process (flux) in (a) $\mathrm{NC}$, (b) SC, and (c) SCB obtained from simulation ANNmet. Blue lines are for DJF and red lines are for JJA. Transport fluxes were calculated at the boundaries while other sources and sinks were calculated as the sums over the grid cells of the region under $1 \mathrm{~km}$.

season, as meteorological fields were kept at a specific year and the same emission scaling factors were applied to all regions.

The differences in MAD and APDM values between ANNmet_ATM and ANNmet represented the IAVs of aerosols caused by meteorology-sensitive natural emissions. The roles of natural emissions were generally small, except that the differences in APDM between ANNmet_ATM and ANNmet were large in DJF and MAM for OC over SC (Table 3), which were caused by the high biogenic emissions in the region $(\mathrm{Fu}$ and Liao, 2012).

\section{Conclusions}

We used the nested grid version of the GEOS-Chem model to estimate the role of meteorology in the IAVs of aerosols over China for years 2004-2012. We performed simulations, ANNmet (effects of variations in meteorology alone), and ANNmet_ATM (same as ANNmet except that meteorology- sensitive natural emissions were turned off), ANNemis (effects of variations in anthropogenic emissions alone), and ANNall (combined effects of variations in meteorology and anthropogenic emissions) to identify the key parameters that influence the IAVs of aerosols.

We defined two parameters, MAD and APDM, to quantify the IAVs in concentrations of aerosols over 2004-2012. Results from simulation ANNmet showed that, driven by changes in meteorological parameters alone, the regional mean APDM values of sulfate, nitrate, and OC aerosols were in the ranges of $10-24 \%, 9-18 \%$, and 6-12\%, respectively, over the studied regions (NC, SC, and SCB) throughout the year. As a result of the IAVs of individual aerosol species, simulated $\mathrm{PM}_{2.5}$ aerosol concentrations exhibited large IAVs in NC, with regionally averaged APDM values of 17, 14, 14, and $11 \%$ in DJF, MAM, JJA, and SON, respectively. Over $\mathrm{SC}$, the IAVs in $\mathrm{PM}_{2.5}$ were found to be the largest in JJA; the regional mean APDM value was $14 \%$ in JJA and about $9 \%$ in other seasons. Concentrations of $\mathrm{PM}_{2.5}$ over SCB were simulated to have the smallest IAVs among the polluted regions examined in this work, with the APDM values of 8$9 \%$ in all seasons. All aerosol species (sulfate, nitrate, ammonium, black carbon, and organic carbon) were simulated to have the largest IAVs over NC in DJF, corresponding to the large variations in meteorological parameters over $\mathrm{NC}$ in DJF.

We applied process analyses for sulfate, nitrate and OC to identify key meteorological parameters that led to IAVs of these aerosols over 2004-2012. For sulfate in NC, gasphase formation of sulfate was found to be the key process that drove the IAV of sulfate in both DJF and JJA, with relative contributions of $30 \%$ in DJF and of $57 \%$ in JJA, inferring that the variations in temperature and specific humidity jointly determined the IAV of sulfate in NC. Over SC and $\mathrm{SCB}$, the most important process that dominated IAV of sulfate in DJF was found to be the vertical flux through the top side with relative contributions of $24 \%$ in SC and $33 \%$ in $\mathrm{SCB}$; and the key process in JJA was found to be wet deposition with relative contributions of $20 \%$ and $35 \%$ in SC and SCB, respectively. For nitrate, gas-to-aerosol conversion was found to be the key process that dominated the IAVs of nitrate over the three regions, with very high relative contributions of $45-62 \%$ in DJF and 71-73\% in JJA, indicating that temperature and specific humidity were the major factors that drove the IAV of nitrate in China. For OC, transport was the most important process that influenced the IAV of OC throughout the year, and precipitation also played a crucial role in JJA over SC and SCB, associated with the East Asian summer monsoon precipitation.

We also examined the relative importance of anthropogenic emissions and meteorological parameters in the IAVs of aerosols. For all aerosol species (sulfate, nitrate, ammonium, BC, and OC), the APDM values in ANNmet were larger than those in ANNemis in NC and SC, indicating that the variations in meteorological parameters played 
more important roles than variations in anthropogenic emissions in driving the IAVs of aerosols in these two regions. In SCB, the variations in emissions were found to be as important as those in meteorological fields for IAVs of nitrate, ammonium, and $\mathrm{PM}_{2.5}$ aerosols in MAM, JJA, and SON.

The IAVs in meteorological fields are mainly associated with natural variability in the climate system; hence the magnitudes of IAVs in aerosol concentrations driven by meteorological parameters have important implications for the effectiveness of short-term air quality control strategies in China. We note that the changes in anthropogenic emissions on longer timescales (for example, decades) may lead to linear trends in simulated aerosol concentrations (Yang et al., 2014). For studies on longer timescales, the MAD and APDM values need to be calculated after detrending the time series, following the approach used in previous studies that examined interannual variations in ozone concentrations (Camp et al., 2003), sea surface temperature, partial pressure of $\mathrm{CO}_{2}$ (Gruber et al., 2002), sea level pressure (Thompson et al., 1998), and North Atlantic Oscillation index (Jung et al., 2003).

Acknowledgements. This work was supported by the National Basic Research Program of China (973 Program, grant no. 2014CB441202), the Strategic Priority Research Program of the Chinese Academy of Sciences Strategic Priority Research Program grant no. XDA05100503, and the National Natural Science Foundation of China under grants 41475137 and 41321064 . We thank the MODIS Atmosphere Discipline Group for providing the MODIS data and anonymous reviewers for helpful suggestions during the review process.

Edited by: V.-M. Kerminen

\section{References}

Alexander, B., Park, R. J., Jacob, D. J., Li, Q. B., Yantosca, R. M., Savarino, J., Lee, C. C. W., and Thiemens, M. H.: Sulfate formation in sea-salt aerosols: Constraints from oxygen isotopes, J. Geophys. Res., 110, D10307, doi:10.1029/2004jd005659, 2005.

Alston, E. J., Sokolik, I. N., and Kalashnikova, O. V.: Characterization of atmospheric aerosol in the US Southeast from ground- and space-based measurements over the past decade, Atmos. Meas. Tech., 5, 1667-1682, doi:10.5194/amt-5-1667-2012, 2012.

Aw, J. and Kleeman, M. J.: Evaluating the first-order effect of intraannual temperature variability on urban air pollution, J. Geophys. Res., 108, 4365, doi:10.1029/2002JD002688, 2003.

Balkanski, Y. J., Jacob, D. J., Gardner, G. M., Graustein, W. C., and Turekian, K. K.: Transport and Residence Times of Tropospheric Aerosols Inferred from a Global 3-Dimensional Simulation of Pb-210, J. Geophys. Res., 98, 20573-20586, doi:10.1029/93jd02456, 1993.

Bellouin, N., Rae, J., Jones, A., Johnson, C., Haywood, J., and Boucher, O.: Aerosol forcing in the Climate Model Intercomparison Project (CMIP5) simulations by HadGEM2-ES and the role of ammonium nitrate, J. Geophys. Res., 116, D20206, doi:10.1029/2011jd016074, 2011.

Bouwman, A. F., Lee, D. S., Asman, W. A. H., Dentener, F. J., VanderHoek, K. W., and Olivier, J. G. J.: A global high-resolution emission inventory for ammonia, Global Biogeochem. Cy., 11, 561-587, doi:10.1029/97GB02266, 1997.

Camp, C. D., Roulston, M. S., and Yung, Y. L.: Temporal and spatial patterns of the interannual variability of total ozone in the tropics, J. Geophys. Res, 108, D4643, doi:10.1029/2001JD001504, 2003.

Cao, J. J., Wang, Q. Y., Chow, J. C., Watson, J. G., Tie, X. X., Shen, Z. X., Wang, P., and An, Z. S.: Impacts of aerosol compositions on visibility impairment in Xi' an, China, Atmos. Environ., 59, 559-566, doi:10.1016/j.atmosenv.2012.05.036, 2012.

Chan, C. K. and Yao, X.: Air pollution in mega cities in China, Atmos. Environ., 42, 1-42, doi:10.1016/j.atmosenv.2007.09.003, 2008.

Chen, D., Wang, Y., McElroy, M. B., He, K., Yantosca, R. M., and Le Sager, P.: Regional CO pollution and export in China simulated by the high-resolution nested-grid GEOS-Chem model, Atmos. Chem. Phys., 9, 3825-3839, doi:10.5194/acp-9-3825-2009, 2009.

Chin, M., Chu, A., Levy, R., Remer, L., Kaufman, Y., Holben, B., Eck, T., Ginoux, P., and Gao, Q. X.: Aerosol distribution in the Northern Hemisphere during ACE-Asia: Results from global model, satellite observations, and Sun photometer measurements, J. Geophys. Res., 109, D23s90, doi:10.1029/2004jd004829, 2004.

Civerolo, K., Hogrefe, C., Zalewsky, E., Hao, W., Sistla, G., Lynn, B., Rosenzweig, C., and Kinney, P. L.: Evaluation of an 18-year CMAQ simulation: Seasonal variations and long-term temporal changes in sulfate and nitrate, Atmos. Environ., 44, 3745-3752, doi:10.1016/j.atmosenv.2010.06.056, 2010.

Dawson, J. P., Adams, P. J., and Pandis, S. N.: Sensitivity of $\mathrm{PM}_{2.5}$ to climate in the Eastern US: a modeling case study, Atmos. Chem. Phys., 7, 4295-4309, doi:10.5194/acp-7-4295-2007, 2007.

Drury, E., Jacob, D. J., Spurr, R. J. D., Wang, J., Shinozuka, Y., Anderson, B. E., Clarke, A. D., Dibb, J., McNaughton, C., and Weber, R.: Synthesis of satellite (MODIS), aircraft (ICARTT), and surface (IMPROVE, EPA-AQS, AERONET) aerosol observations over eastern North America to improve MODIS aerosol retrievals and constrain surface aerosol concentrations and sources, J. Geophys. Res., 115, D14204, doi:10.1029/2009jd012629, 2010.

Duan, F., He, K., Ma, Y., Yang, F., Yu, X., Cadle, S., Chan, T., and Mulawa, P.: Concentration and chemical characteristics of $\mathrm{PM}_{2.5}$ in Beijing, China: 2001-2002, Sci. Total Environ., 355, 264-275, doi:10.1016/j.scitotenv.2005.03.001, 2006.

Fairlie, T. D., Jacob, D. J., and Park, R. J.: The impact of transpacific transport of mineral dust in the United States, Atmos. Environ., 41, 1251-1266, doi:10.1016/j.atmosenv.2006.09.048, 2007.

Fairlie, T. D., Jacob, D. J., Dibb, J. E., Alexander, B., Avery, M. A., van Donkelaar, A., and Zhang, L.: Impact of mineral dust on nitrate, sulfate, and ozone in transpacific Asian pollution plumes, Atmos. Chem. Phys., 10, 3999-4012, doi:10.5194/acp-10-39992010, 2010.

Fountoukis, C. and Nenes, A.: ISORROPIA II: a computationally efficient thermodynamic equilibrium model for $\mathrm{K}^{+}-\mathrm{Ca}^{2+}$ $\mathrm{Mg}^{2+}-\mathrm{NH}_{4}^{+}-\mathrm{Na}^{+}-\mathrm{SO}_{4}^{2-}-\mathrm{NO}_{3}^{-}-\mathrm{Cl}^{-}-\mathrm{H}_{2} \mathrm{O}$ aerosols, At- 
mos. Chem. Phys., 7, 4639-4659, doi:10.5194/acp-7-4639-2007, 2007.

Fu, Y. and Liao, H.: Simulation of the interannual variations of biogenic emissions of volatile organic compounds in China: Impacts on tropospheric ozone and secondary organic aerosol, Atmos. Environ., 59, 170-185, doi:10.1016/j.atmosenv.2012.05.053, 2012.

Fu, Q. Y., Zhuang, G. S., Wang, J., Xu, C., Huang, K., Li, J., Hou, B., Lu, T., and Streets, D. G.: Mechanism of formation of the heaviest pollution episode ever recorded in the Yangtze River Delta, China, Atmos. Environ., 42, 2023-2036, doi:10.1016/j.atmosenv.2007.12.002, 2008.

Fu, T.-M., Cao, J. J., Zhang, X. Y., Lee, S. C., Zhang, Q., Han, Y. M., Qu, W. J., Han, Z., Zhang, R., Wang, Y. X., Chen, D., and Henze, D. K.: Carbonaceous aerosols in China: top-down constraints on primary sources and estimation of secondary contribution, Atmos. Chem. Phys., 12, 2725-2746, doi:10.5194/acp12-2725-2012, 2012.

Gonçalves, M., Jiménez-Guerrero, P., and Baldasano, J. M.: Contribution of atmospheric processes affecting the dynamics of air pollution in South-Western Europe during a typical summertime photochemical episode, Atmos. Chem. Phys., 9, 849-864, doi:10.5194/acp-9-849-2009, 2009.

Gong, S., Zhao, T., Sharma, S., Toom-Sauntry, D., Lavoué, D., Zhang, X., Leaitch, W., and Barrie, L.: Identification of trends and interannual variability of sulfate and black carbon in the Canadian High Arctic: J. Geophys. Res., 115, D07305, doi:10.1029/2009JD012943, 2010.

Gruber, N., Bates, N. R., and Keeling, C. D.: Interannual variability in the North Atlantic Ocean carbon sink, Science, 298, 23742378, doi:10.1126/science.1077077, 2002.

Guenther, A., Karl, T., Harley, P., Wiedinmyer, C., Palmer, P. I., and Geron, C.: Estimates of global terrestrial isoprene emissions using MEGAN (Model of Emissions of Gases and Aerosols from Nature), Atmos. Chem. Phys., 6, 3181-3210, doi:10.5194/acp-63181-2006, 2006.

Habib, G., Venkataraman, C., Chiapello, I., Ramachandran, S., Boucher, O., and Reddy, M. S.: Seasonal and interannual variability in absorbing aerosols over India derived from TOMS: Relationship to regional meteorology and emissions, Atmos. Environ., 40, 1909-1921, doi:10.1016/j.atmosenv.2005.07.077, 2006.

Huang, C., Chen, C. H., Li, L., Cheng, Z., Wang, H. L., Huang, H. Y., Streets, D. G., Wang, Y. J., Zhang, G. F., and Chen, Y. R.: Emission inventory of anthropogenic air pollutants and VOC species in the Yangtze River Delta region, China, Atmos. Chem. Phys., 11, 4105-4120, doi:10.5194/acp-11-4105-2011, 2011.

Huang, X., Song, Y., Li, M. M., Li, J. F., Huo, Q., Cai, X. H., Zhu, T., Hu, M., and Zhang, H. S.: A high-resolution ammonia emission inventory in China, Global Biogeochem. Cy., 26, Gb1030, doi:10.1029/2011gb004161, 2012.

Im, U., Markakis, K., Poupkou, A., Melas, D., Unal, A., Gerasopoulos, E., Daskalakis, N., Kindap, T., and Kanakidou, M.: The impact of temperature changes on summer time ozone and its precursors in the Eastern Mediterranean, Atmos. Chem. Phys., 11, 3847-3864, doi:10.5194/acp-11-3847-2011, 2011.

Jiang, F., Zhou, P., Liu, Q., Wang, T. J., Zhuang, B. L., and Wang, X. Y.: Modeling tropospheric ozone formation over East China in springtime, J. Atmos. Chem., 69, 303-319, doi:10.1007/s10874012-9244-3, 2012.
Jiang, Z., Liu, Z., Wang, T., Schwartz, C. S., Lin, H.-C., and Jiang, F.: Probing into the impact of 3DVAR assimilation of surface $\mathrm{PM}_{10}$ observations over China using process analysis, J. Geophys. Res., 118, 6738-6749, doi:10.1002/jgrd.50495, 2013.

Jose, R. S., Perez, J. L., Pleguezuelos, C., Camacho, F., and Gonzalez, R. M.: MM5-CMAQ air quality modelling process analysis: Madrid case, Adv. Air Pollut. Ser., 11, 171-179, 2002.

Jung, T., Hilmer, M., Ruprecht, E., Kleppek, S., Gulev, S. K., and Zolina, O.: Characteristics of the recent eastward shift of interannual NAO variability, J. Climate, 16, 3371-3382, 2003.

Kharol, S., Martin, R. V., Philip, S., Vogel, S., Henze, D. K., Chen, D., Wang, Y., Zhang, Q., and Heald, C. L.: Persistent Sensitivity of Asian Aerosol to Emissions of Nitrogen Oxides, Geophys. Res. Lett., 40, 1021-1026, doi:10.1002/grl.50234, 2013.

Kim, J. Y., Song, C. H., Ghim, Y. S., Won, J. G., Yoon, S. C., Carmichael, G. R., and Woo, J. H.: An investigation on $\mathrm{NH}_{3}$ emissions and particulate $\mathrm{NH}_{4}^{+}-\mathrm{NO}_{3}^{-}$formation in East Asia, Atmos. Environ., 40, 2139-2150, doi:10.1016/j.atmosenv.2005.11.048, 2006.

Kleeman, M. J.: A preliminary assessment of the sensitivity of air quality in California to global change, Climatic Change, 87, S273-S292, doi:10.1007/s10584-007-9351-3, 2008.

Liao, H., Chen, W. T., and Seinfeld, J. H.: Role of climate change in global predictions of future tropospheric ozone and aerosols, $\mathrm{J}$ Geophys. Res., 111, D12304, doi:10.1029/2005jd006852, 2006.

Liu, H. Y., Jacob, D. J., Bey, I., and Yantosca, R. M.: Constraints from ${ }^{210} \mathrm{~Pb}$ and ${ }^{7} \mathrm{Be}$ on wet deposition and transport in a global three-dimensional chemical tracer model driven by assimilated meteorological fields, J. Geophys. Res., 106, 1210912128, doi:10.1029/2000jd900839, 2001.

Lu, Z., Zhang, Q., and Streets, D. G.: Sulfur dioxide and primary carbonaceous aerosol emissions in China and India, 1996-2010, Atmos. Chem. Phys., 11, 9839-9864, doi:10.5194/acp-11-98392011, 2011.

Mahowald, N., Luo, C., del Corral, J., and Zender, C. S.: Interannual variability in atmospheric mineral aerosols from a 22-year model simulation and observational data, J. Geophys. Res., 108, 4352, doi:10.1029/2002jd002821, 2003.

Martin, R. V., Jacob, D. J., Yantosca, R. M., Chin, M., and Ginoux, P.: Global and regional decreases in tropospheric oxidants from photochemical effects of aerosols, J. Geophys. Res., 108, 4097, doi:10.1029/2002jd002622, 2003.

Murray, L. T., Jacob, D. J., Logan, J. A., Hudman, R. C., and Koshak, W. J.: Optimized regional and interannual variability of lightning in a global chemical transport model constrained by LIS/OTD satellite data, J. Geophys. Res., 117, D20307, doi:10.1029/2012JD017934, 2012.

Park, R. J., Jacob, D. J., Chin, M., and Martin, R. V.: Sources of carbonaceous aerosols over the United States and implications for natural visibility, J. Geophys. Res., 108, 4355, doi:10.1029/2002jd003190, 2003.

Park, R. J., Jacob, D. J., Field, B. D., Yantosca, R. M., and Chin, M.: Natural and transboundary pollution influences on sulfate-nitrate-ammonium aerosols in the United States: Implications for policy, J. Geophys. Res., 109, D15204, doi:10.1029/2003jd004473, 2004.

Park, R. S., Song, C. H., Han, K. M., Park, M. E., Lee, S.-S., Kim, S.-B., and Shimizu, A.: A study on the aerosol optical properties over East Asia using a combination of CMAQ-simulated 
aerosol optical properties and remote-sensing data via a data assimilation technique, Atmos. Chem. Phys., 11, 12275-12296, doi:10.5194/acp-11-12275-2011, 2011.

Piao, S. L., Fang, J. Y., Zhou, L. M., Guo, Q. H., Henderson, M., Ji, W., Li, Y., and Tao, S.: Interannual variations of monthly and seasonal normalized difference vegetation index (NDVI) in China from 1982 to 1999, J. Geophys. Res., 108, 4401, doi:10.1029/2002jd002848, 2003.

Pye, H. O. T., Liao, H., Wu, S., Mickley, L. J., Jacob, D. J., Henze, D. K., and Seinfeld, J. H.: Effect of changes in climate and emissions on future sulfate-nitrate-ammonium aerosol levels in the United States, J. Geophys. Res., 114, D01205, doi:10.1029/2008jd010701, 2009.

Qian, W. and Lin, X.: Regional trends in recent precipitation indices in China, Meteorol. Atmos. Phys., 90, 193-207, doi:10.1007/s00703-004-0101-z, 2005.

Qu, W. J., Arimoto, R., Zhang, X. Y., Zhao, C. H., Wang, Y. Q., Sheng, L. F., and Fu, G.: Spatial distribution and interannual variation of surface $\mathrm{PM}_{10}$ concentrations over eighty-six Chinese cities, Atmos. Chem. Phys., 10, 5641-5662, doi:10.5194/acp-105641-2010, 2010.

Racherla, P. N. and Adams, P. J.: Sensitivity of global tropospheric ozone and fine particulate matter concentrations to climate change, J. Geophys. Res., 111, D24103, doi:10.1029/2005jd006939, 2006.

Sauvage, B., Martin, R. V., van Donkelaar, A., Liu, X., Chance, K., Jaeglé, L., Palmer, P. I., Wu, S., and Fu, T.-M.: Remote sensed and in situ constraints on processes affecting tropical tropospheric ozone, Atmos. Chem. Phys., 7, 815-838, doi:10.5194/acp-7-815-2007, 2007.

Streets, D. G., Bond, T. C., Carmichael, G. R., Fernandes, S. D., Fu, Q., He, D., Klimont, Z., Nelson, S. M., Tsai, N. Y., Wang, M. Q., Woo, J. H., and Yarber, K. F.: An inventory of gaseous and primary aerosol emissions in Asia in the year 2000, J. Geophys. Res., 108, 8809, doi:10.1029/2002jd003093, 2003.

Sun, Y. L., Wang, Z. F., Fu, P. Q., Yang, T., Jiang, Q., Dong, H. B., Li, J., and Jia, J. J.: Aerosol composition, sources and processes during wintertime in Beijing, China, Atmos. Chem. Phys., 13, 4577-4592, doi:10.5194/acp-13-4577-2013, 2013.

Tai, A. P. K., Mickley, L. J., and Jacob, D. J.: Correlations between fine particulate matter $\left(\mathrm{PM}_{2.5}\right)$ and meteorological variables in the United States: Implications for the sensitivity of $\mathrm{PM}_{2.5}$ to climate change, Atmos. Environ., 44, 3976-3984, doi:10.1016/j.atmosenv.2010.06.060, 2010.

Thompson, D. W. J. and Wallace, J. M.: The arctic oscillation signature in the wintertime geopotential height and temperature fields, Geophys. Res. Lett., 25, 1297-1300, doi:10.1029/98GL00950, 1998.

van der Werf, G. R., Randerson, J. T., Giglio, L., Collatz, G. J., Kasibhatla, P. S., and Arellano Jr., A. F.: Interannual variability in global biomass burning emissions from 1997 to 2004, Atmos. Chem. Phys., 6, 3423-3441, doi:10.5194/acp-6-3423-2006, 2006.

van Donkelaar, A., Martin, R. V., Park, R. J., Heald, C. L., Fu, T. M., Liao, H., and Guenther, A.: Model evidence for a significant source of secondary organic aerosol from isoprene, Atmos. Environ., 41, 1267-1274, doi:10.1016/j.atmosenv.2006.09.051, 2007.
Wang, Y., Zhang, Q. Q., He, K., Zhang, Q., and Chai, L.: Sulfatenitrate-ammonium aerosols over China: response to 2000-2015 emission changes of sulfur dioxide, nitrogen oxides, and ammonia, Atmos. Chem. Phys., 13, 2635-2652, doi:10.5194/acp-132635-2013, 2013.

Wesely, M. L.: Parameterization of surface resistance to gaseous dry deposition in regional scale numerical models, Atmos. Environ., 23, 1293-1340, 1989.

Xia, X., Chen, H., and Wang, P.: Validation of MODIS aerosol retrievals and evaluation of potential cloud contamination in East Asia, J. Environ. Sci., 16, 832-837, 2004.

Yang, F., Huang, L., Duan, F., Zhang, W., He, K., Ma, Y., Brook, J. R., Tan, J., Zhao, Q., and Cheng, Y.: Carbonaceous species in $\mathrm{PM}_{2.5}$ at a pair of rural/urban sites in Beijing, 2005-2008, Atmos. Chem. Phys., 11, 7893-7903, doi:10.5194/acp-11-78932011, 2011.

Yang, Y., Liao, H., and Lou, S.: Decadal trend and interannual variation of outflow of aerosols from East Asia: Roles of variations in meteorological parameters and emissions, Atmos. Environ., submitted, 2014.

Yao, X., Chan, C. K., Fang, M., Cadle, S., Chan, T., Mulawa, P., He, $\mathrm{K}$., and Ye, B.: The water-soluble ionic composition of $\mathrm{PM}_{2.5}$ in Shanghai and Beijing, China, Atmos. Environ., 36, 4223-4234, doi:10.1016/s1352-2310(02)00342-4, 2002.

Ye, B., Ji, X., Yang, H., Yao, X., Chan, C. K., Cadle, S. H., Chan, T., and Mulawa, P. A.: Concentration and chemical composition of $\mathrm{PM}_{2.5}$ in Shanghai for a 1-year period, Atmos. Environ., 37, 499-510, 2003.

Yienger, J. J. and Levy, H.: Empirical model of global soil-biogenic $\mathrm{NO}_{\mathrm{X}}$ emissions, J. Geophys. Res., 100, 11447-11464, 1995.

Zhang, Q., Streets, D. G., Carmichael, G. R., He, K. B., Huo, H., Kannari, A., Klimont, Z., Park, I. S., Reddy, S., Fu, J. S., Chen, D., Duan, L., Lei, Y., Wang, L. T., and Yao, Z. L.: Asian emissions in 2006 for the NASA INTEX-B mission, Atmos. Chem. Phys., 9, 5131-5153, doi:10.5194/acp-9-5131-2009, 2009.

Zhang, Y., Vijayaraghavan, K., Wen, X. Y., Snell, H. E., and Jacobson, M. Z.: Probing into regional ozone and particulate matter pollution in the United States: 1. A 1 year CMAQ simulation and evaluation using surface and satellite data, J. Geophys. Res., 114, D22304, doi:10.1029/2009jd011898, 2009.

Zhang, L., Liao, H., and Li, J. P.: Impacts of Asian summer monsoon on seasonal and interannual variations of aerosols over eastern China, J. Geophys. Res., 115, D00k05, doi:10.1029/2009jd012299, 2010a.

Zhang, Y., Dore, A. J., Ma, L., Liu, X. J., Ma, W. Q., Cape, J. N., and Zhang, F. S.: Agricultural ammonia emissions inventory and spatial distribution in the North China Plain, Environ. Pollut., 158, 490-501, doi:10.1016/j.envpol.2009.08.033, 2010 b.

Zhang, Q., Geng, G., Wang, S., Richter, A., and He, K.: Satellite remote sensing of changes in NOx emissions over China during 1996-2010, Chinese Sci. Bull., 57, 2857-2864, doi:10.1007/s11434-012-5015-4, 2012.

Zhu, J. L., Liao, H., and Li, J. P.: Increases in aerosol concentrations over eastern China due to the decadal-scale weakening of the East Asian summer monsoon, Geophys. Res. Lett., 39, L09809, doi:10.1029/2012g1051428, 2012. 